\title{
Intellectual Property, Antitrust, and the Rule of Law: Between Private Power and State Power
}

\begin{abstract}
Ariel Katz*
This Article explores the rule of law aspects of the intersection between intellectual property and antitrust law. Contemporary discussions and debates on intellectual property (IP), antitrust, and the intersection between them are typically framed in economically oriented terms. This Article, however, shows that there is more law in law than just economics. It demonstrates how the rule of law has influenced the development of several IP doctrines, and the interface between IP and antitrust, in important, albeit not always acknowledged, ways. In particular, it argues that some limitations on IP rights, such as exhaustion and limitations on tying arrangements, are grounded in rule of law principles restricting the arbitrary exercise of legal power, rather than solely in considerations of economic efficiency. The historical development of IP law has reflected several tensions, both economic and political, that lie at the heart of the constitutional order of the modern state: the tension between the benefits of free competition and the recognition that some restraints on competition may be beneficial and justified; the concern that power, even when conferred in the public interest, can often be abused and arbitrarily
\end{abstract}

* Associate Professor and Innovation Chair - Electronic Commerce, Faculty of Law, University of Toronto. An earlier version of this Article was presented at The Constitution of Information: From Gutenberg to Snowden conference, held at the University of Toronto Faculty of Law on May 28-29, 2015. The conference was organized with the cooperation and support of Tel Aviv University's Cegla Center for Interdisciplinary Research of the Law and Theoretical Inquiries in Law, and with a contribution from Google Canada. I wish to thank my colleague Lisa Austin, who organized the conference with me, as well as the other speakers and participants for their comments and insights. I also wish to thank Aaron Perzanowski and Guy Rub for their comments, Eden Sarid, Michael Stenbring, and Matthew Marinett for their research assistance, and the Social Sciences and Humanities Research Council of Canada for supporting this research. 
applied to advance private interests; and the tension between freedom of contract and property and freedom of trade. This Article explores how rule of law considerations have allowed courts to mediate these tensions, both in their familiar public law aspects but also in their less conspicuous private law dimensions, and how, in particular, they have shaped the development of IP doctrine and its intersection with antitrust law and the common law.

\section{INTRODUCTION}

This Article explores the rule of law aspects of the intersection between intellectual property, antitrust, and the rule of law. Contemporary discussions and debates on intellectual property (IP), antitrust, and the intersection between them are typically framed in economically oriented terms. In antitrust, economic efficiency has not only become the predominant metric for the analysis of specific legal rules, but according to some it constitutes the sole legitimate goal of antitrust law as a whole. ${ }^{1}$ In a similar vein, economically oriented cost-benefit arguments tend to dominate contemporary discussions on IP law. From this perspective, the central challenge for IP law lies in designing a system that facilitates an optimal tradeoff between the supposed benefits of IP rights (enhanced creativity and innovation) and the costs that such exclusivity imposes on access to and use of the works and innovation thus created.

Scholars, courts, and antitrust enforcers dealing with questions at the interface of both areas of law nowadays describe IP and antitrust laws as acting in tandem to accomplish the same overarching goals: "to maximize wealth by producing what consumers want at the lowest cost"" and "encourag[e] innovation, industry and competition." ${ }^{3}$ Within this framework, IP laws do their part by providing "incentives for innovation and its dissemination and commercialization by establishing enforceable property rights for the creators of new and useful products, more efficient processes, and original works of expression," while antitrust law complements IP and "promote[s] innovation

1 Camden Hutchison, Law and Economics Scholarship and Supreme Court Antitrust Jurisprudence, 1950-2010, 20 LEwIS \& CLARK L. REV. (forthcoming 2016); see also Barak Orbach, Was the Crisis in Antitrust a Trojan Horse?, 79 Antitrust L.J. 881 (2014).

2 Ward Simon Bowman, Patent and Antitrust Law: A Legal and Economic ApPraisal 1 (1973).

3 Atari Games Corp. v. Nintendo of America, Inc., 897 F.2d 1572, 1576 (Fed. Cir. 1990).

4 U.S. Dep't of Justice \& Fed. Trade Comm'n, Antitrust Guidelines for the 
and consumer welfare by prohibiting certain actions that may harm competition with respect to either existing or new ways of serving consumers." ${ }^{\prime}$ A great deal of the discourse in the area (including my own scholarship) involves competing narratives on how deciding cases or formulating more general rules one way or the other would impact innovation and other measures of social welfare, which are also discussed in predominantly economic terms.

Historically, however, both areas of law evolved with more than economic considerations in mind. Rule of law principles, similar to those which constitutional and administrative law lawyers are versed in, have played a central role in the development of the law in these areas, and they continue to do so today, albeit in less noticed ways. In a recent article titled The Antitrust Constitution, ${ }^{6}$ Tom Nachbar has demonstrated how economic theory cannot account for several persistent features of antitrust doctrine, and argued that antitrust law's concern about harm to "competition" is better viewed as consisting of two distinct harms: the familiar "market harm," described and measured as a harm to efficiency, but also a "regulatory harm" — harm to the freedom of choice felt by those participating in the market. ${ }^{7}$ He suggested that "antitrust is of a piece with a much larger body of law that governs the proper exercise of regulatory authority, a body of law more closely associated with constitutional theory than economic theory." Antitrust law does not merely provide rules of economic regulation, but also establishes a set of rules against private regulation. ${ }^{9}$

This Article discusses a similarly neglected aspect of IP law, focusing on one important principle of the rule of law: the principle that any restraints on a person's freedom must be grounded in a recognized legal rule, and that the courts will not enforce any restraint that is not so grounded. The Article brings to light the following legal proposition and discusses the central role it has played in the development of IP law and its intersection with antitrust: Patents and copyrights are legal monopolies, as this term has been used since at least the sixteenth century. ${ }^{10}$ That is, they are statutory grants that restrain people from doing things that they would otherwise be free to do under the common law. Because patents and copyrights give their owners power over

Licensing of Intellectual Property $§ 1.0$ (1995), http://www.usdoj.gov/atr/ public/guidelines/0558.pdf.

Id.

6 Thomas B. Nachbar, The Antitrust Constitution, 99 Iowa L. Rev. 57 (2013).

$7 \quad I d$. at 69.

$8 \quad I d$.

$9 \quad I d$.

10 Oren Bracha, Monopolies, in 4 The Oxford InTERnATIOnAl EnCyClopedia of Legal History 186 (Stanley N. Katz ed., 2009). 
the exercise of the common law rights of others, their exclusionary power must not only be grounded in a recognized legal rule, but also be bounded by law. Thus, determining the scope of IP rights and the limitations on their exercise involves more than balancing economic interests, and ultimately relies on the general principles of the rule of law.

Struggles over who has the legal authority to promulgate and enforce rules that restrain the liberties of others has been a central motif in the development of England's constitutional law, and the common narrative describes the gradual decline of royal prerogative and the corresponding ascendance of Parliament. Some of the famous struggles concerned the power to levy taxes and other forms of the exercise of state power - questions that continue to occupy constitutional and administrative law lawyers. But other contentions involved the power to grant monopolies or otherwise delegate lawmaking powers to private entities, and the proper exercise of those powers. ${ }^{11}$ I think there will be a better flow if the sentence is: in large part, the laws on monopolies and the common law doctrines against restraint of trade and restraint on alienation were forged in the context of these constitutional debates. Economic considerations have played a role in those debates and in courts' decisions, but ultimately the courts made their decisions on the basis of legal principles that reflected political and constitutional theory, not economic theory.

Many of these rule of law principles migrated to North America and other former British colonies, but by the mid nineteenth century, with the rise of laissez faire philosophies, courts' interests in the limits on the exercise of legal powers by private actors had diminished. However, the passage of the antitrust laws towards the end of the nineteenth century generated renewed interest in those constitutional questions, and they played a pivotal role in a series of key decisions of the U.S. Supreme Court since the beginning of the twentieth century, including decisions in IP and antitrust cases. ${ }^{12}$ This Article tracks the development of those rule of law principles and the ways in which their evolution was intertwined with and continues to influence the development of IP law, antitrust law, and the common law doctrines on restraint of trade and restraints on alienation.

This Article proceeds as follows. The next two Parts discuss the concept of the rule of law that I employ in this Article and its historical development. Part III highlights how the same rule of law principles informed the development of several private law common law rules, such as the doctrines against restraint of trade and alienation, while Part IV discusses the rule of law aspects of antitrust and their connection to due process and nondelegation doctrine. In

11 See infra Part II.

12 See infra Part IV. 
Part V, I revisit key IP decisions that many economically minded analysts have considered puzzling if not outright misguided. I show that a careful reading of these decisions - which deal with exhaustion of IP rights, tying, and contributory liability - reveals that rule of law considerations, not economic theory, were at the heart of the courts' decisions. The courts were more concerned with setting boundaries to the exercise of the legal powers delegated to IP owners than with optimizing the degree of IP owners' market power and deciding whether its exercise promotes or hinders efficiency.

\section{The Rule of LaW}

\section{A. A Working Definition}

That the rule of law is a central tenet of any liberal democracy is almost axiomatic, ${ }^{13}$ even if widespread agreement on what this term actually means is hard to come by. ${ }^{14}$ My goal in this Article is not to offer a general theory of the rule of law, but only to expose the latent role of one aspect of the rule of law in the development of IP law and its intersection with antitrust. The aspect of the rule of law that I focus on is the proposition that, in the words of A.V. Dicey, the prominent nineteenth century British constitutional law scholar,

no man is punishable or can be lawfully made to suffer in body or goods except for a distinct breach of law established in the ordinary legal manner before the ordinary Courts of the land. In this sense the rule of law is contrasted with every system of government based on the exercise by persons in authority of wide, arbitrary, or discretionary powers of constraint. ${ }^{15}$

In Dicey's view, the rule of law included two additional aspects: that no man is above the law, that officials are bound by the same laws as ordinary

13 E.g., Canadian Charter of Rights and Freedoms, The Constitution Act, 1982, being Schedule B to the Canada Act 1982, c 11, pmbl. (U.K.); MARGaret JANE Radin, Boilerplate: The Fine Print, Vanishing Rights, and the Rule of Law 37 (2012).

14 See, e.g., Richard H. Fallon, Jr., The Rule of Law as a Concept in Constitutional Discourse, 97 Colum. L. Rev. 1 (1997); Peter W. Hogg \& Cara F. Zwibel, The Rule of Law in the Supreme Court of Canada, 55 U. Toronto L.J. 715, 717 (2005); Thomas B. Nachbar, Defining the Rule of Law Problem, 6 GREEN BAG 303, 304 (2009); Margaret Jane Radin, Reconsidering the Rule of Law, 69 B.U. L. Rev. 781 (1989); see also Paul Gowder, The Rule of Law in the Real World 1-2 (2016).

15 A.V. Dicey, Introduction to the Study of the Law of the Constitution 183-84 (Macmillan \& Co. 8th ed. 1927) (1889). 
subjects, ${ }^{16}$ and that the common law courts play a crucial role in the recognition and protection of individual rights and other constitutional principles. ${ }^{17}$ For Dicey, the rule of law was synonymous with the supremacy of law, ${ }^{18}$ by which he meant "the security given under the English constitution to the rights of individuals," 19 and "the absolute supremacy or predominance of regular law as opposed to the influence of arbitrary power, and excludes the existence of arbitrariness, of prerogative, or even of wide discretionary authority on the part of the government." ${ }^{20}$

\section{B. Defining "Law"}

The Diceyan understanding of the rule of law also requires clarification of what constitutes "law." A law, for Dicey's purposes, means "any rule which will be enforced by the Courts." 21 "Law" includes the common law, as well as "[a]ny Act of Parliament, or any part of an Act of Parliament, which makes a new law, or repeals or modifies an existing law." 22 Likewise, parliamentary sovereignty implies that "[t]here is no person or body of persons who can, under the English constitution, make rules which override or derogate from an Act of Parliament, or which (to express the same thing in other words) will be enforced by the Courts in contravention of an Act of Parliament."23

Parliament's exclusive lawmaking power does not imply that no other persons or bodies are capable of promulgating rules that will be enforced by the courts. Indeed, Dicey described a panoply of "non-sovereign lawmaking bodies," such as chartered railway companies, school boards, or town councils. ${ }^{24}$ These bodies have lawmaking powers in the sense that the rules they promulgate might be enforceable by the courts. For example, an English

\section{$16 I d$. at 189. \\ 17 Id. at 191-92. \\ $18 \quad I d$. at 179. \\ 19 Id. at 180. \\ $20 \quad I d$. at 198. \\ 21 Id. \\ $22 I d$. \\ 23 Id. at 8.}

24 For Dicey, the category of non-sovereign lawmaking bodies also includes legislative bodies such as the parliaments of the British Colonies, or the parliaments of countries such as Belgium or France, which, while they may be properly called "legislatures," are not truly sovereign bodies: the former, because they derive their power from and are subordinate to the British Parliament and to the power of the imperial government to disallow their statutes, $i d$. at 113-14, and the latter, because they are legislative but not constitutive bodies, and therefore are limited 
railway company may be empowered, statutorily, to make bylaws allowing it to regulate traveling upon the railway, as well as to impose a penalty for the breach of such bylaws, which can then be enforced by the courts. ${ }^{25}$ The railway company, thus, can make "laws," but it has no sovereign lawmaking powers, because (a) it is subordinate to and has to comply with the Act of Parliament creating the company and all other laws; (b) while it can make and change its bylaws, it lacks the power to change the Act that constitutes it; and (c) the courts determine the validity of the company's bylaws, ${ }^{26}$ and decide whether, in enacting and implementing its bylaws, the company acted within the powers conferred upon it by Parliament, or beyond them. ${ }^{27}$

Although in many important respects the traditional Westminster parliamentary sovereignty is quite different from constitutional supremacy, to which countries such as both Canada and the United States subscribe, the historical circumstances that led to principles of parliamentary sovereignty and their legal and intellectual heritage continue to be relevant throughout the entire Anglo-American legal tradition and its concept of the rule of law. The crucial point for the current discussion is that the power to make new laws or to abridge existing laws lies within the exclusive domain of the legislature. As a result, any person purporting to enforce any law, impose a penalty or fine, or deprive another person of her liberty or possessions, must show that her claim is based on a valid legal rule, either a rule of the common law or a rule of statutory law. Without such basis, the court will decline to enforce the claim. As I show below, the same principles have played an important role in the development of both intellectual property law and antitrust.

\section{The Historical Development of the Rule of Law}

The roots of the modern concept of rule of law can be traced back to the early modern period. Until the end of the sixteenth century, English common law supported a legal and economic order that tightly controlled individuals' economic activities and limited the opportunities available to them. ${ }^{28}$ But the sixteenth century saw the decline of the Church and medieval modes of social, political, and economic organization, alongside the rise of individualism on the

by the written constitutions of those countries, which they lack the power to modify, id. at 120-21.

25 Id. at $90-91$.

26 Id. at $91-92$.

27 Id. at 94.

28 Michael J. Trebilcock, The Common Law of Restraint of Trade: A Legal and Economic AnAlysis 10-11 (1986). 
one hand and of strong centralized governments on the other. ${ }^{29}$ These changes also transformed the common law, which has grown increasingly averse to this system of regulation and privilege and had to develop a framework that could distinguish between legitimate and illegitimate restraints.

In England, these developments fueled prolonged constitutional power struggles concerning the scope of royal prerogative. The Stuart monarchs relied on asserted extensive prerogative powers to grant monopolies, levy taxes, dispense with certain laws, as well as to adjudicate and enforce the law. But the ambition of their claims met a growing and equally ambitious opposition, ${ }^{30}$ and those asserted powers were challenged before the courts and in Parliament, eventually resulting in the decline of royal prerogative and the corresponding triumph of English constitutionalism based on Parliamentary sovereignty and the supremacy of law. However, similar principles also emerged in contexts we would consider today as private law, such as the development of doctrines against contracts in restraint of trade, and limitations on restraints of alienation of property. ${ }^{31}$ It was also during this period that the prototypes of modern copyright and patent laws began to take shape. Thus, the struggles surrounding the scope of royal prerogative resulted in legal principles that would not only give rise to the rule of law and the supremacy of law, but also influence certain key aspects of modern IP and antitrust laws.

The next sections describe some key legal moments in these historical developments and their interconnectedness.

\section{A. The Struggle over Monopolies}

The scope of royal prerogative to grant monopolies and patents played an important role in the development of English constitutionalism and the rule of law around the turn of the seventeenth century. To modern economically trained ears, the term "monopoly" connotes questions of antitrust and economic policy, and the term "patent" connotes questions of IP law and innovation policy. But while the debates on monopolies and patents during the sixteenth century included economic concerns, their fundamental question was not economic but constitutional. The focus of the debates was not the optimal level of intervention in the free operation of the market, or how to stimulate innovation, but the question of who had the power to make laws that interfered with the rights of individuals.

29 Id.

30 John V. Orth, Did Sir Edward Coke Mean What He Said?, 16 Const. Comment. 33, 36 (1999).

31 Indeed, the contemporary distinction between public and private control of trade practices developed much later. See Nachbar, supra note 6, at 79-80. 
The term "monopoly" has described, at least since the first half of the sixteenth century, the grant of various commercial and industrial privileges to individuals or companies. ${ }^{32}$ The grants of such privileges often took the form of Letters Patent, hence the term "patent." Lord Coke defined a monopoly as

an institution, or allowance by the king by his grant, commission, or otherwise to any person or persons, bodies politique, or corporate, of or for the sole buying, selling, making, working, or using of any thing, whereby any person or persons, bodies politique, or corporate, are sought to be restrained of any freedome, or liberty that they had before, or hindred in their lawfull trade. ${ }^{33}$

Monopolies took different forms, serving different purposes and functions. ${ }^{34}$ The first type resembled today's patents: exclusive rights granted to inventors of new technologies, or those who introduced foreign technologies into England. ${ }^{35}$ The second type were non obstante patents, namely patents exempting the patentees from certain regulations and prohibitions. ${ }^{36}$ While sometimes justified as a method for fine-tuning regulation, those patents were increasingly granted as a means of favoritism or as a way of raising revenue for the Crown. ${ }^{37}$ The third type were monopolies granting regulatory authority over particular trades, ${ }^{38}$

32 Bracha, supra note 10.

333 Edward Coke, Institutes of the laws of ENGLAND ch. 85 (1797).

34 For the early history of monopolies in England since the fourteenth century and the growth of their use by Queen Elizabeth during the second half of the sixteenth century, see William Hyde Price, The English Patents of Monopoly 5 (1913).

35 Thomas B. Nachbar, Monopoly, Mercantilism, and the Politics of Regulation, 91 VA. L. ReV. 1313, 1324 (2005).

36 Id. at 1325.

37 Id.

38 For example, prior to the enactment of the first copyright statute in 1709 , patents of the first kind, granting exclusive rights to print, distribute, and import books, were given to publishers of new books, or of certain popular titles. However, in addition to those patents, when the publication and distribution of books which the Crown considered seditious or heretical, "by divers scandalous malicious schismatical and heretical persons," became widespread, the Crown instituted a licensing regime, prohibiting the publication, distribution or importation of any book not authorized by the competent state or church authorities. Stationers Charter, London (1557), Primary SouRCES ON COPYRIGHT (1450-1900) (Lionel Bently \& Martin Kretschmer eds.), http://www.copyrighthistory.org/cam/tools/ request/showRepresentation?id=representation_uk_1557. A crucial component of the licensing regime was the monopoly granted to the London Company of Stationers over the book trade, which entrusted it with extensive powers to 
allowing the grantee to license and supervise other trades. ${ }^{39}$ Another variant involved the right to collect fines for violations of trade regulations. Those patents were not used to punish violations in order to stop them, but simply to extract fees from tradesmen in exchange for continuing the de jure prohibited practice. ${ }^{40}$ Lastly, monopolies were granted for no particular reason other than as an assertion of royal prerogative. ${ }^{41}$ The lines between the different categories were not necessarily clear, and patents could have mixed features. ${ }^{42}$ But despite the differences, they all shared a common economic feature: they would confer upon the patentees the power to extract rents from the economic activities subject to the patents, at least where that exclusivity was enforced, or where competing patents would not dissipate those rents. ${ }^{43}$

Towards the end of the sixteenth century the widespread use of royal monopolies, and the inevitable resulting abuses, had become a source of growing political and legal agitation. In Darcy v. Allen (The Case of Monopolies), ${ }^{44}$ the Court invalidated a patent granted by Queen Elizabeth, which conferred a monopoly on the manufacture and importation of playing cards. The Court held that the grant of the monopoly was "against the common law, and the benefit and liberty of the subject," 45 because it, like "any other monopoly, is not only a damage and prejudice to those who exercise the same trade, but also to all other subjects, for the end of all these monopolies is for the private gain of the patentees. ${ }^{~} 46$

The Court (or at least Lord Coke's account of the decision ${ }^{47}$ ) explained that monopolies were harmful for several reasons: they tend to raise prices,

enforce the licensing regime and with a source of monopoly rents that provided its members with an economic incentive to maintain this censorship regime. See Ian A. Gadd, 'A Suitable Remedy'? Regulating the Printing Press, 1553-1558, in Catholic Renewal and Protestant Resistance in Marian England 127, 139-41 (Elizabeth Evenden \& Vivienne Westbrook eds., 2015).

39 Nachbar, supra note 35 , at 1325.

40 Id.

41 Id.

$42 I d$.

43 Id.

44 Darcy v. Allen (The Case of Monopolies) (1602) 77 Eng. Rep. 1260 (KB).

45 Id. at $1262-63$

46 Id. at 1263.

47 Coke himself was Attorney General at the time and actually acted for the plaintiff and argued that the patent was valid. The only report of the case was Coke's. It was published in 1615, and is suspected to reflect more of Coke's own hostile views towards monopolies and crown prerogative than a true reflection of the court's decision. Nevertheless, Coke's report has been accepted and treated as 
"for he who has the sole selling of any commodity, may and will make the price as he pleases," ${ }^{48}$ and reduce quality because "after the monopoly [is] granted, the commodity is not so good and merchantable as it was before: for the patentee having the sole trade, regards only his private benefit, and not the commonwealth." ${ }^{\prime 9}$ And finally, the monopoly "tends to the impoverishment of divers artificers and others, who before, by the labour of their hands in their art or trade, had maintained themselves and their families, who now will of necessity be constrained to live in idleness and beggary." ${ }^{.50}$ Equating one's livelihood to his life, the Court held that a man should not be deprived or disposed of his trade, no more than of his life. ${ }^{51}$

While echoing modern concerns about monopolies, Coke's antipathy should not be mistaken as evincing a deep belief in economic liberalism, or free trade as such. ${ }^{52}$ Lord Coke might have understood that monopolies might result in higher prices, lower quality, and "idleness" (which today we might refer to as "deadweight loss"), but the mercantilist economic thinking of the time approved of various types of monopolies. Monopolies for new inventions were considered legitimate (just as they are today), as were monopolies encouraging the importation of foreign technologies to England. ${ }^{53}$ These monopolies were viewed to be consistent with the common law because they not only carried some benefits with them, but also, limited to hitherto unknown or unpracticed trades, they were not seen as depriving anyone from practicing any lawful trade. ${ }^{54}$ Likewise, prohibitions or limitations on the importation of various goods (which contemporary economic thinking would regard as a protectionist faux pas) were not considered objectionable inasmuch as their goal was to protect domestic manufacturers from foreign competition. ${ }^{55}$

Indeed, one such Act of Parliament prohibited the importation of cards to protect domestic manufacturers. ${ }^{56}$ Therefore, the "liberty of the subject" argument — relied on to invalidate the manufacturing monopoly — could

a true account of the decision. See Jacob I. Corré, The Argument, Decision, and Reports of Darcy v. Allen, 45 EMORY L.J. 1261, 1263-64 (1996).

48 Darcy, 77 Eng. Rep. at 1263.

49 Id.

$50 \quad I d$.

$51 \quad I d$.

52 Nachbar, supra note 35.

53 Harold G. Fox, Monopolies and Patents: A Study of the History and Future of the Patent Monopoly 27 (1947).

54 Nachbar, supra note 35, at 1338.

55 Barbara Malament, The "Economic Liberalism" of Sir Edward Coke, 76 YalE L.J. 1321 (1967).

56 Darcy, 77 Eng. Rep. at 1266. 
not be relied on directly for invalidating the plaintiff's importation monopoly, because the importation monopoly did not restrain the defendant's liberty to import cards more than the Act of Parliament did. Challenging the importation monopoly required somewhat different legal grounds, which the Court indeed provided.

The importation monopoly was in the form of a non-obstante patent: it permitted Darcy and only Darcy to import playing cards notwithstanding an Act of Parliament prohibiting that very same thing. It was held that even if the grant of the importation patent was a valid exercise of the Queen's dispensation power and thereby provided the patentee immunity from prosecution for violation of the statutory prohibition on importation of cards, it was void inasmuch as it purported to confer upon the plaintiff an exclusive right to import cards. ${ }^{57}$ The patent was void because it was a monopoly against the common law as well as an attempt to usurp the intention of Parliament to protect local manufacturers. ${ }^{58}$

These nuances illustrate that while the concerns about monopolies were not devoid of economic considerations, the objection to the grant of monopolies was not based on their impact on total welfare. The greater concerns were legal, and indeed constitutional, regarding the power to grant and revoke legal rights and the power to make laws and determine their scope. Monopolies were understood to interfere with the common law rights of every member of the community to carry on any trade or business as he chooses, but it was also widely accepted that many such interferences were warranted and even desirable to promote the common good. The question, then, was not whether such interference with common law rights and freedoms could ever be legitimate, or what the optimal level of intervention in the free operation of the market would be, but who has the power to interfere with those rights and freedoms. That power could only be exercised by Parliament.

57 Id. There appears to be a debate about whether the court made any decision on the scope of the dispensation prerogative in this case. The common report of the case, written by Coke, suggests that the court held that the dispensation power did not apply to an Act of Parliament of that kind, id. at 1265, but a footnote in a later report suggests that the court never decided this question and that it did not have to because it held that the patent was void vis-à-vis the defendant, $i d$. at $1265 \mathrm{n} . \mathrm{G}$.

$58 I d$. at 1266. In Coke's view, while the royal prerogative allowed the king to grant non obstante patents dispensing with certain statutes, the king could never dispense with the common law, because the common law was the inheritance of all Englishmen, which only Parliament, but not the king, could take away. See Glenn Burgess, Absolute Monarchy and the Stuart Constitution 195 (1996). 


\section{B. Monopolies and Taxation}

The question of monopolies was closely related to the question of taxation. The roots of the constitutional principle that no taxes could be levied without the consent of the House of Commons can be traced back to at least the Magna Carta, although the issue was only settled after the Glorious Revolution and the passage of the Bill of Rights, $1869 .{ }^{59}$ Parliament's power over taxation could serve as an effective means of holding the king accountable; if the king's own resources are insufficient to finance his extravagant domestic and foreign affairs, preventing the king from levying taxes without Parliamentary consent makes the king dependent on and accountable to Parliament. Monopolies, however, provided the monarchs a convenient way to raise revenue while subverting Parliamentary oversight. ${ }^{60}$ The grant of a monopoly typically required the grantee to share its revenue with the king, and the constant threat of royal insolvency pushed the monarchs to grant more and more monopolies. ${ }^{61}$ The constitutional principle of no taxation without representation would be easily subverted if the king could use royal prerogative to grant monopolies.

The questions surrounding monopolies and taxation were part of a broader constitutional struggle over the power to make laws, the process of making and applying them, and the power to determine their scope and reach. Similar questions arose in the context of proclamations.

\section{The Struggle to Establish the Supremacy of the Law}

The Case of Proclamations from 1610 concerned the question of the king's power to legislate by issuing proclamations. Lord Coke, as Chief Justice of the Common Pleas, and his fellow judges held that the king could not "by his proclamation of other ways . . change any part of the common law, or

59 For example, the Case of Impositions involved the question of whether the king could, as part of his prerogative and without Parliament, impose import duties to increase his revenue. Bates, the defendant, imported currants from Venice, but refused to pay the custom duties, arguing that their imposition was illegal. The Barons of the Exchequer held that while the king could not impose a duty on Bates without Parliament, the king's absolute prerogative on matters of foreign trade allowed him to impose a duty on and for the currants, a foreign good, upon their importation to England. Bates' Case (Case of Impositions) (1606) 2 St. Tr. 371, 388. According to Glenn Burgess, Coke initially supported this holding, though by 1610 he argued that no impositions could be set without the consent of Parliament. Burgess, supra note 58, at 198.

60 Nachbar, supra note 35, at 1344.

61 BuRgESs, supra note 58, at 198. 
statute law, or the customs of the realm ..., nor create any [new] offence, ... [and] has no prerogative but that which the law of the land allows him." ${ }^{2}$

Establishing the rule of law and the supremacy of law also involved the question of who has the power to adjudicate, interpret, pronounce, and enforce the law. This question was dealt with in the Case of Prohibitions (Prohibitions del Roy). ${ }^{63}$ The case was a milestone in establishing the supremacy of the common law courts as the final arbiters of legal matters, as opposed to other tribunals such as the ecclesiastical courts, or prerogative courts, such as the Star Chamber. The case began with a disagreement concerning the jurisdiction of the ecclesiastical courts. When such disagreements arose, the common law courts could issue a writ of prohibition enjoining the ecclesiastical court from hearing the matter. The Archbishop of Canterbury, however, advised King James I that when such questions arise before the courts, "the King himself may decide it in his Royal person; and that the Judges are but the Delegates of the King, and that the King may take what causes he shall please to determine, from the determination of the Judges, and may determine them himself." ${ }^{64}$ Lord Coke, as Chief Justice of the Common Pleas, informed the King that "the King in his own person cannot adjudge any case . . . but this ought to be determined and adjudged in some Court of Justice, according to the law and custom of England." 65

These common law courts' decisions did not result in an immediate change in monarchical practices. The kings did not cede their powers immediately, and continued granting monopolies, levying customs by impositions, and ruling by the issue of proclamations, typically relying on the Star Chamber, itself a prerogative court, to enforce them. It took several more decades, legislative action, and one "glorious" revolution until those matters were settled and codified in the Bill of Rights from 1688. ${ }^{66}$ The next Section describes some of those legislative efforts.

\section{From the Statute of Monopolies to the Bill of Rights}

Many of the principles decided in the abovementioned cases were subsequently codified in Acts of Parliament. The Statute of Monopolies, ${ }^{67}$ which Coke

62 Case of Proclamations [1610] EWHC KB J22, http://www.bailii.org/ew/cases/ EWHC/KB/1610/J22.html.

63 Case of Prohibitions (1607) 12 Co. Rep. 63 (KB).

64 Id.

65 Id. at 63-64.

66 Bill of Rights Act (1688), c. 21 Will. \& Mar. Sess. 2.

67 Statute of Monopolies Act (1623), c. 3, Ja. 1. 
drafted and championed, and to which King James I eventually assented, represents another landmark in the process of entrenching many of the rule of law principles discussed above. It began by declaring that

all monopolies, and all commissions, grants, licences, charters and letters patents ... of or for the sole buying, selling, making, working or using of any thing ... are altogether contrary to the laws of this Realm, and so are and shall be utterly void and of none effect, and in no wise to be put in ure or execution. ${ }^{68}$

Note that the declaration is confirmatory: it declares and affirms existing law, rather than making unlawful that which had been lawful before. The declaration was not limited to commercial exclusive rights but also extended to non obstante monopolies, as well as "all proclamations, inhibitions, restraints, warrants of assistance, and all other matters and things whatsoever, any way tending to the instituting, erecting, strengthening, furthering or countenancing of the same or any of them ...." ${ }^{69}$ The statute, after providing the most sweeping prohibition, turned to exempt certain monopolies, such as patents granted to the first and true inventors of new manufactures, monopolies granted under an Act of Parliament, printing patents, and several specific monopolies that were grandfathered. ${ }^{70}$

The Statute of Monopolies also sought to establish the supremacy of the common law courts. Many patents at the times contained clauses referring disputes to the Privy Councill, ${ }^{71}$ and the Privy Council and its Star Chamber routinely issued orders preventing the common law courts from exercising jurisdiction over patent cases. ${ }^{72}$ Such clauses and orders rendered judicial decisions invalidating monopolies, such as Darcy v. Allen, both rare $^{73}$ and insignificant: if patents could be enforced by order of the Star Chamber and not subject to the jurisdiction of the common law courts, then the Crown (and its favorites) were, in effect, above the law; the Crown could, by virtue of its prerogative, create a parallel legal order, where it could abridge the common law rights and freedom of its subjects and impose financial burdens without the consent of Parliament and the oversight of the courts. Section 2 of the Statute of Monopolies sought to address this problem by providing that "all

$68 I d . \S 1$. The phrase "put in ure" means to make use, employ, apply, put something into effect, bring about, as well as bring forward a legal action. See Hans Kurath et al., Ure, 4 Middle English Dictionary 498 (1998).

69 Statute of Monopolies $\S 1$.

70 Id. $\S 5$ et seq.; see also Nachbar, supra note 35, at 1349-52.

71 PRICE, supra note 34, at 17-18 n.4.

72 Nachbar, supra note 35, at 1333.

73 PRICE, supra note 34, at 17-18 n.4. 
monopolies ... . and the force and validity of them, and every of them, ought to be, and shall be for ever hereafter examined, heard, tried, and determined, by and according to the common laws of this realm, and not otherwise." 74 Moreover, section 4 provided that any person injured by an unlawful monopoly shall have a remedy and could initiate legal action in the common law courts, as well as recover treble damages and double costs. ${ }^{75}$

Additional notable legislative milestones include the Petition of Right, 1627, which reaffirmed the common law principles of freedom from arbitrary arrest and imprisonment, due process in the administration of justice, and parliamentary consent to taxation; ${ }^{76}$ the abolition of the Star Chamber in $1641 ;^{77}$ and finally, the passage of the Bill of Rights following the "Glorious Revolution" and the restoration of the monarchy. The Act listed and then prohibited several objectionable practices of the previous king, which were characterized as "endeavour[s] to subvert and extirpate the protestant religion, and the laws and liberties of this kingdom" "78: assuming and exercising a power of dispensing with and suspending laws and the execution of laws without consent of Parliament; continuing the practice of erecting special prerogative courts; and levying money for and to the use of the Crown by pretense of prerogative without the approval of Parliament. ${ }^{79}$ To a large extent, then, these statutes codified, and eventually settled, many of the principles that the common law courts had previously established and would continue to develop over the subsequent centuries.

74 Statute of Monopolies § 2; see also William L. Letwin, The English Common Law Concerning Monopolies, 21 U. CHI. L. Rev. 355, 362 (1954).

75 Statute of Monopolies $\S 4$.

76 Robert Blackburn, Magna Carta and the Development of the British Constitution, Historian, Spring 2015, at 26, 28. The Petition of Right itself was prompted by King Charles I's attempt to extract forced loans from a variety of citizens. Five knights refused to provide the forced loans and were imprisoned. The court of the King's Bench refused their petition for a writ of habeas corpus, and the Parliamentary debate that ensued led to the Petition of Right. See Paul Gowder, The Rule of LaW in the Real World 134 (2016).

77 An Act for the Regulating of the Privy Council, and for taking away the Court commonly called the Star Chamber, 17 Car., c. 10 (1641), http://oll.libertyfund. org/pages/1641-the-act-for-the-abolition-of-the-court-of-star-chamber.

78 Bill of Rights Act (1688), c. 21 Will. \& Mar. Sess. 2, pmbl.

79 Id. 


\section{The Public and Private Aspects of the Rule of Law}

The notion of the rule of law typically connotes limitations on the exercise of power by public officials, or individuals exercising statutory powers, such as statutory corporations ${ }^{80}$ But the notion of the rule of law as the supremacy of law, distinct from the rule of men exercising arbitrary power, prerogative, or wide discretionary authority over others, invokes a richer and substantive concept of the rule of law. Margaret Radin, for example, intimated such a deeper view of the rule of law when she stated that the rule of law, as opposed to the rule of men, "calls upon us to strive to ensure that our law itself will rule (govern) us, not the wishes of powerful individuals," ${ }^{81}$ and "to conceive of ourselves as a people governed by its law rather than by arbitrary individual power." 82 As others have already noted, the rule of law in its deeper meaning also permeates private law. ${ }^{83}$

The idea that the rule of law pervades the law in its entirely would not strike seventeenth century lawyers as surprising. Indeed, a sharp distinction between "private" and "public" law was foreign to the legal and political thought of Coke and his contemporaries. Unlike Roman civil law, which drew a clear distinction between "private" and "public" law, the importance of the common law, writes Glenn Burgess, "lay in its very "privateness," and its organizing principle was the guarantee it provided of the individual's property, inheritance and birthright. ${ }^{84}$ The powers of the crown were defined more by way of declaring how it could not interfere with the private rights of individuals than by defining what it was allowed to do. ${ }^{85}$

80 In addition to a formal aspect whereby the rule of law must mean, at a minimum, rule by law, see Aharon Barak, The Judge in a Democracy 54 (2006), the rule of law may connote a jurisprudential conception, focusing on certain minimum requirements, such as the desiderata offered by Fuller or other legal philosophers, which distinguish a legal system from other coercive social orders, $i d$. It may further extend to include certain substantive human rights, such as guarantees of "fundamental values of morality, justice, and human rights, with a proper balance between these and the other needs of society." Id. at 55. These issues are beyond the scope of this Article.

81 Radin, supra note 14, at 781.

82 Id. at 813.

83 Lisa M. Austin \& Dennis Klimchuk, Introduction, in Private LaW AND the Rule of Law 1, 6 (Lisa M. Austin \& Dennis Klimchuk eds., 2014).

84 Burgess, supra note 58, at 170-71.

85 Id. at 171. Likewise, Dicey emphasized that the general principles of the English constitution resulted from judicial decisions determining the private rights of individuals, and contrasted the English constitution with other systems where 
Thus, the common law defined the property right of the individual, the property right of the king, and the king's relationship to the property of his subjects. ${ }^{86}$ Royal prerogative itself was perceived merely as a type of common law right, derived from and bounded by the common law, and therefore did not allow the king to modify the common law or interfere with the common law rights of others. The common law itself was the inheritance of all Englishmen. The rights it afforded to individuals could not be taken away without consent, expressed in an Act of Parliament, for the same reasons that royal prerogative could also not be taken away without royal assent. ${ }^{87}$

The "privateness" of the rule of law explains how similar reasoning shaped doctrines dealing not only with the exercise of public powers but also the exercise of private powers, and how they have constrained the legal powers of individuals just as they constrain the powers of officials. The Case of Monopolies provides an easy example. From the plaintiff's perspective, the dispute between Darcy and Allen appears to be rooted in private law: a plaintiff, a private person, alleged that the defendant, another private person, infringed the plaintiff's right and that the plaintiff suffered damages as a result. ${ }^{88}$ From the defendant's perspective, however (and from that of the court), the dispute bears the hallmarks of public law: a defendant asserting certain liberties, and claiming that the royal grant purporting to restrict them was ultra vires and invalid. Therefore, the plaintiff's private law claim was predicated entirely on a public law question: did the Queen have the power to grant the plaintiff's patent? If the Queen's prerogative did not allow her to restrict the defendant's liberties, then she could not possibly delegate such powers to the plaintiff, and the plaintiff could have no valid cause of action against the defendant and no grounds to seek redress.

The Tailors of Ipswich case, ${ }^{89}$ decided in 1614, provides another easy example of the publicness of private law or the privateness of public law. In that case, the Tailors' Company of Ipswich sought to enforce a bylaw providing that no person shall practice his trade within the town of Ipswich until he presented himself to the company, proved that he had served at least seven years as an apprentice, and was admitted by the company. The company was incorporated under letters patent granted by the King, which authorized it to promulgate reasonable rules as necessary for its good governance, as well

the protection of private rights depended on their recognition in a preexisting constitution. DiceY, supra note 15, at 191.

86 Burgess, supra note 58, at 170.

87 Id. at 195.

88 Darcy v. Allen (The Case of Monopolies) (1602) 77 Eng. Rep. 1260 (KB) 1261.

89 The Case of the Tailors of Ipswich (1615) 11 Co. Rep. 53a (KB). 
as to impose fines for their breach. ${ }^{90}$ The defendant was an apprenticed tailor who had come to Ipswich and been hired by a resident of Ipswich to serve as a tailor for his family. He worked for twenty days prior to presenting himself to the company. The company sought to fine him for failure to comply, which he refused to pay.

The court, per Chief Justice Coke, held the bylaw void. He began by stating the common law's aversion to monopolies and restraints of trade, echoing the reasoning of Darcy v. Allen..$^{91}$ But whereas in Darcy the patent was invalidated on the basis that the queen lacked the power to grant that kind of patent, there was no argument in the Taylors case that the letters patent were invalid or that the King could not grant the company powers to promulgate bylaws and enforce them. Moreover, the apprenticeship requirement in the bylaw merely tracked the requirement in the Statute of Artificers, ${ }^{92}$ which prohibited every person from practicing any trade unless he had served as an apprentice for seven years ${ }^{93}$ and therefore this aspect of the bylaw could not have restrained the defendant's common law freedoms more than Parliament had already done.

The issue, then, was not the validity of the grant of powers to the company, ${ }^{94}$ but the exercise of those powers and, specifically, whether in promulgating the specific bylaws the company had acted within the scope of its patent or beyond it. This required the court to construe both the scope of the restraint imposed by Parliament as well as the scope of the company's powers. The court held that the company's bylaw exceeded both. The statutory apprenticeship requirement did not help the company, because it only confirmed the principle that "without an Act of Parliament, none can be in any manner restrained from working in any lawful trade." 95 Parliament only imposed a mandatory apprenticeship requirement, but it did not restrain anyone who had completed the apprenticeship period from exercising his trade. The company, however, required that the person also be admitted by it. Moreover, the court construed the Act as regulating only the "public use and exercise of a trade to all who will come," but not restraining anyone from exercising his trade privately "in the house of any family." ${ }^{96}$ The company, however, purported to regulate such private acts as well.

$90 \quad I d$.

91 Id. at 53b.

92 Statute of Artificers 5 Eliz. c. 4.

93 The Case of the Tailors of Ipswich, 11 Co. Rep. at 54a.

94 Malament, supra note 55, at 1336.

95 The Case of the Tailors of Ipswich, 11 Co. Rep. at 54a.

96 Id. 
The court held that it was only lawful to promulgate "[o]rdinances for the good order and government of men of trades," but not those that "restrain any one in his lawful mystery." 97 Therefore, the bylaw was invalid because enacting it was not within the powers granted to the company, and because inasmuch as it exceeded the scope of the restraints created by Parliament, it was "against the liberty and freedom of the subject," and could be applied arbitrarily as "a means of extortion." 98

The Taylors of Ipswich case is notable for several reasons. First, as Sarah Bilder argued, the origins of judicial review, a crucial component of the rule of law, can be traced to this case and other earlier and contemporaneous attempts to control the powers of corporations..$^{99}$ Second, like Darcy v. Allen, it subjected the acts of individuals and corporations exercising delegated regulatory powers to judicial review. As I discuss in the next Part, important aspects of IP law and antitrust can be understood as setting similar limits on the exercise of delegated regulatory power by private entities.

Third, recall that the company's power to promulgate and enforce bylaws had not been challenged. Arguably, then, if the company has the power to enact enforceable bylaws then it must have some power to restrain others in ways not specifically sanctioned by Parliament. Therefore, if the bylaws were to be invalid merely because they purported to restrain more than the common law or an Act of Parliament permitted, then any bylaw could be invalid. The Court resolved this apparent tension between the grant of regulatory power and the need to limit this power by distinguishing between the restraints that the company could impose and those that it could not. It could enact bylaws pertaining to "the good order and government of men of trades" because they are ancillary to the company's regulatory mandate, but it could not go further "to restrain any one in his lawful mystery." 100 The distinction is similar to the one between reasonable and unreasonable restraint developed in the restraint of trade cases that I discuss below.

Fourth, we can think about the main constitutional question in Darcy v. Allen as a first-order question: was the grant of the monopoly within the scope of royal prerogative, or could it only be granted by Parliament? And we can think about the question in the Taylors of Ipswich case as dealing with a second-order constitutional question: assuming or accepting that the delegation of some regulatory powers to the company was lawful, what is the

$97 \quad I d$.

98 Id.

99 Mary Sarah Bilder, The Corporate Origins of Judicial Review, 116 Yale L.J. 503 (2006).

$100 \mathrm{Id}$. 
scope of those powers? The following sections discuss the private restraint of trade cases - private in the sense that they concern restraints that emanate from the exercise of one or more parties' common law rights as opposed to the exercise of powers conferred by statutory or royal grants. These cases deal with a third-order question: are there limits to the exercise of private power by persons disposing of their property or entering into contracts with others?

\section{A. Restraints on Alienation of Property}

Rule of law considerations can explain the common law rules with respect to restraints on alienation and with respect to contracts in restraint of trade. In the case of the former, courts often revert to the following passage from Lord Coke's Institutes of the Laws of England as the statement of the rule:

[I]f a man be possessed of a lease for years, or of a horse, or of any other chattel real or personal, and give or sell his whole interest or property therein, upon condition that the donee or vendee shall not alien the same, the same is void, because his whole interest and property is out of him, so as he hath no possibility of a reverter, and it is against trade and traffic, and bargaining and contracting between man and man. ${ }^{101}$

The statement does not proclaim an indiscriminate rule that prevents parties from entering into transactions involving various conditions. Indeed, the statement itself is qualified to a sale without a possibility of reverter, and is included in a chapter of titled "estates upon condition," which describes various forms of permissible conditions, distinguished from those that are void. The reason why the described attempt to restrain the alienation of an asset is void appears to lie in the seller's attempt to limit the legal entitlement of others,

because when a man so insossed of lands, or tenements, he has power to alienate them to any person by the law. For if such a condition should be good, then the condition should oust him of all power which the law gives him, which should be against reason, and therefore such a condition is void. ${ }^{102}$

Thus, only the law can define the rights of a seller and those of the buyer, not the seller. The statement "against reason" does not mean that there could not possibly be legitimate reasons why conditions could be valid. In Coke's

1011 Edward Coke, Institutes of the Laws of England $§ 360$ (1797).

$102 I d$. 
writings "reason" and "common law" were often synonyms. ${ }^{103}$ Therefore, the restraint is "against reason" because it purports to derogate from the rights that the law allocates to the buyer and constitutes an attempt by the seller to create new law.

It is interesting to compare the statement on the rule against alienation to another statement in another context where Coke explained that

the King himself cannot create a perfect Manor at this day, for such things as receive their perfection by the continuance of time, come not within the compasse of a Kings Prerogative, and therefore the King cannot grant Freehold to hold by Copie, neither can the King create any new custome, nor doe any thing that amounteth to the creation of a new custome. ${ }^{104}$

A seller cannot restrain the buyer from selling what he had purchased for the same reason that the king cannot create new types of estates. The legal entitlements of sellers and buyers are defined by the common law, shaped through generations of customs. Hence, they can only evolve the way the common law evolves or be changed by Parliament. If the king does not have the prerogative to create new types of estates then sellers cannot use their own prerogative of selling their property to impose unrecognized legal obligations on others.

From a rule of law perspective, monopolies granted by the king, restrictive regulations promulgated by guilds, and restraints on alienation share a common feature: in all such cases plaintiffs seek to enlist the coercive power of the state by asking courts to prevent another member of the community from exercising that person's "common law right . . . to carry on any trade or business he chooses in such a manner as he thinks most desirable in his own interests." 105 The rule of law, or the notion of the supremacy of law, then dictates that the court decline to enforce the restraint, unless the plaintiff can demonstrate a valid legal basis for interference with the defendant's common law rights. Such a valid legal basis could come from a patent lawfully acquired and lawfully granted, a recognized common law rule, or an Act of Parliament allowing one person to impose restraints on another but not from the seller's own will.

103 Burgess, supra note 58, at 184.

104 Edward Coke, The Compleat Copyholder, in Edward Coke, Three Law Tracts $1, \S 31$ (William Hawkins ed., 1764).

105 Fox, supra note 53, at 9. 


\section{B. Contracts in Restraint of Trade}

Contracts, in general, allow parties to restrain themselves, and the law of contracts provides the legal basis that makes those restraints enforceable. Nevertheless, under the doctrine of contracts in restraint of trade some restraints would not be enforceable. Superficially, contractual restraints, inasmuch as their enforceability is predicated on the parties' consent, might seem qualitatively different from involuntary restraints that inhere in the grant of monopolies, or even from restraints on alienation of property, inasmuch as those restraints could attach to and run with the property and affect third parties who were not privy to the original transaction. It might seem erroneous to apply the same logic that invalidates involuntary restraints to voluntary ones. Owning property entails the right to sell that property and to enter into contract with others with respect to its use, and being a free person entails the right to enter into contract with others for the parties' mutual advantage. It would seem, then, that the law should uphold voluntary restraints for the same reasons that it sustains any other good contract. ${ }^{106}$ Courts would endorse this view in the nineteenth century, but during the early modern period the courts were inclined to invalidate contracts that deprived a man of the means to earn a livelihood, or that seemed to deprive the public of the advantages of competition. ${ }^{107}$ Thus, in Colgate v. Bacherel, ${ }^{108}$ the King's Bench declined to order the defendant to pay a bond he undertook to pay should his son work as a haberdasher within two specified cities during a certain number of years. The court held that it was unlawful to prohibit or restrain any person to use a lawful trade and it did not matter whether the restraint applied to all places at all times or to one place and for a limited time. ${ }^{109}$

Several years later, however, in Rogers v. Parrey, ${ }^{110}$ the courts began recognizing the legitimacy of certain restraints, such as those pertaining to the preservation of the goodwill upon the sale of a business, so long as their duration and location were limited. ${ }^{111}$ Those cases culminated in Mitchel $v$. Reynolds, ${ }^{112}$ where the court distinguished between involuntary and voluntary restraints, and identified which may be upheld and which invalidated. Involuntary

106 Letwin, supra note 74, at 375-76.

$107 \mathrm{Id}$.

108 Colgate v. Bacherel (1601) Cro. Eliz. 872, 78 Eng. Rep. 1097 (KB).

109 Id. The court also held that it did not matter that the bond permitted the defendant to pay twenty pounds and void the obligation. This option constituted an equally unlawful restraint.

110 Rogers v. Parrey (1613) 2 Bulst. 136, 80 Eng. Rep. 1012 (KB).

111 TREBILCOCK, supra note 28, at 9.

112 Mitchel v. Reynolds (1711) 1 P. Wms. 181, 24 Eng. Rep. 347 (QB). 
restraints were monopolies, whether customary or under royal grants and charters. Those would be typically void, except in cases involving patents for new inventions or customs and bylaws regulating trades in the public interest. Voluntary restraints could also be void if the restraints were general, in the sense of lacking a specific legitimate purpose or extending beyond what was reasonable for achieving the purpose, while specific restraints given with adequate consideration and pertaining to and proportionate with a legitimate purpose could be considered reasonable and valid. ${ }^{113}$

The doctrine has transformed considerably since its original formulation in the mercantilist era. By the second half of the nineteenth century the courts had embraced a laissez-faire philosophy that emphasized the freedom of contract and property dimension above all other dimensions. "Free consent" had grown to be the almost singular factor for determining the validity of restrictive covenants. ${ }^{114}$ Moreover, the courts also reversed the burden of invalidating contracts in restraint of trade: restraints of trade were no longer prima facie invalid, which meant that those who wished to invalidate the restraints had to establish their reasonableness, and the courts added additional hurdles that made it virtually impossible to show that an agreement entered into with free consent could be against public policy. ${ }^{115}$ This approach was not limited to restrictive covenants in employment contexts, but also carried over to the law relating to combinations, with the courts routinely upholding outright cartelistic agreements and limiting the bases for challenging them. ${ }^{116}$ The notion that general restraints would always be void was replaced with the view that general restraints would only be void if they were unreasonable, ${ }^{117}$ and courts would rarely find unreasonable a contract that was freely entered into between parties. Unreasonableness as between the parties was limited only to situations where fraud or coercion could be proven or if there was no consideration at all. ${ }^{118}$ Courts became reluctant to entertain public policy considerations, taking the position that those considerations should be left for the legislature, and to the extent that they would consider public policy, freedom of contract and enforceability of contracts emerged as the paramount consideration. ${ }^{119}$

113 TREBILCOCK, supra note 28, at 10-11.

$114 \mathrm{Id}$. at 23.

$115 \mathrm{Id}$. at 25-26.

116 Id. at 23-26.

$117 \mathrm{Id}$. at 23.

118 Id. at 28-29.

119 Id. at $18,40$. 
Towards the end of the nineteenth century, the doctrine of contracts in restraint of trade would begin to transform again. Lord Macnaghten's formulation of the doctrine in Nordenfelt v. Maxim Nordenfelt Guns \& Ammunition Co. ${ }^{120}$ has provided the basis for a modern and revived version of the doctrine. ${ }^{121} \mathrm{He}$ stated that "the public have an interest in every person's carrying on his trade freely: so has the individual" and therefore, as a general rule "[a]11 interference with individual liberty of action in trading, and all restraints of trade of themselves, if there is nothing more, are contrary to public policy, and therefore void." However, "restraints of trade and interference with individual liberty of action may be justified by the special circumstances of a particular case" and justification may be found if the restriction is "reasonable in reference to the interests of the parties concerned and reasonable in reference to the interests of the public, so framed and so guarded as to afford adequate protection to the party in whose favour it is imposed, while at the same time it is in no way injurious to the public." ${ }^{122}$ While it is questionable whether the House of Lords in Nordenfelt considered its holding as departing from the perceived wisdom of the laissez faire era, Lord Macnaghtan's formulation would later allow courts to fill the reasonableness test with a modern understanding of reasonableness between the parties and broader considerations of public policy. ${ }^{123}$

As Michael Trebilcock writes, despite the transformations that this common law doctrine has undergone during its various phases of existence, a common thread of continuity runs through the law and reflects an underlying public policy goal - the protection of an individual's right to work - and two values or principles that justify that goal: equity and fairness with respect to the impact of the restraint on the restrained party, and the broader economic benefits that result from trade that is not unduly restrained. The differences between the different phases of the doctrine reflect different understandings of those elements. ${ }^{124}$

However, rule of law principles connect the private and public aspects of the doctrine and further connect the doctrine with the broader issues of individual rights and freedoms and limits on the exercise of legal power, whether public or private. When one party calls upon the court to enforce a contract in restraint of trade, this party asks the court to deprive another member of the community of that member's right. This might present a

120 Nordenfelt v. Maxim Nordenfelt Guns \& Ammunition Co., Ltd. [1894] AC 535 (HL).

121 TREBILCOCK, supra note 28, at 45.

122 Nordenfelt, [1894] AC at 565.

123 TREBILCOCK, supra note 28, at 43-53.

$124 \mathrm{Id}$. at 53-54. 
challenge to the rule of law and the supremacy of the law because if the court were to enforce the restraint indiscriminately then in some circumstances (e.g., situations involving unequal bargaining power) some individuals would be subject to the wishes of powerful individuals rather than being governed by the rules that reflect the collective preferences of the polity. Just as the rule of law ensures that the exercise of power by public officials will not be unconstrained, the doctrine of restraint of trade ensures that individuals will be governed by law and not by arbitrary individual power.

However, rule of law considerations extend beyond the relationships between the immediate parties and they are not limited to situations involving unequal bargaining power. Indeed, private restraints can be mutually advantageous, and parties may agree to be bound by them because the restraint confers benefits on both parties while it imposes costs on third parties or the general public. ${ }^{125}$ The public interest in trade that is free from such restraints includes the economic benefits of competitive markets, but is not limited to them. Rather, the doctrine reflects the recognition that restraints on trade deprive some individuals of their opportunity to pursue their chosen trade as they see fit, and that they might also deprive the public or parts of the public of the benefits of free trade and equal opportunity. But recall that the aversion to restraints of trade has never reflected endorsement of market fundamentalism and laissez faire capitalism, ${ }^{126}$ and that at its core it reflects the constitutional imperative that decisions of that kind, which affect the rights of members of the community, ought not to be left entirely to individual decision makers.

Therefore, the rule of law provides the jurisprudential link connecting the debates around the scope of royal prerogative, monopolies and voluntary restraints of trade. In all of those cases the common law was invoked as a

125 For example, when competitors agree to lessen competition among themselves they may gain by limiting output and increasing prices, which will enable them to collect monopoly rents at the expense of the public. Some vertical restraints (i.e., not between competitors but between firms at different levels of the distribution chain, such as between a producer and distributor) could also have a similar effect. Even though generally it would not be in a firm's self-interest to agree to a vertical restraint that confers market power on a firm situated above or below it in the distribution chain, see Ariel Katz, The First Sale Doctrine and the Economics of Post-Sale Restraints, 2014 BYU L. REv. 55, 71-72 (2014), it might still be induced to enter such an agreement if the other firm agrees to share some of the rents it could collect, or if not agreeing could make it even worse off, see, e.g., Margaret C. Levenstein \& Valerie Y. Suslow, How Do Cartels Use Vertical Restraints? Reflections on Bork's The Antitrust Paradox, 57 J.L. \& Econ. Supp. 33 (2014).

126 See supra notes 52-58 and accompanying text. 
background of legal rules that prevent various types of encroachment upon the rights of individuals. The common law was referred to as the "ancient constitution," which guarantees the rights and liberties of the subjects. ${ }^{127}$ Those rights and liberties were the legal "inheritance" of every subject, which could not be limited, except under the law, and could not be modified or taken away except by an Act of Parliament.

From this perspective, the difference between contracts and the grant of monopolies is not as dramatic as it may seem initially. Recall that when parties enter into a binding contract and can call upon the court to enforce their obligations or seek redress for their breach, their contract constitutes "law" under Dicey's definition. ${ }^{128}$ Indeed, "[t] he obligation of a contract is the law which binds the parties to perform their agreement." 129 However, contracting parties can only make law for themselves under and within the law of the land, not above it. The law defines and constrains their powers just as it defines the powers of public officials. "A contract has no legal force apart from the law that acknowledges its binding character." ${ }^{130}$ A contract's efficacy and binding nature depend on an underlying body of common law and statutes, which "enter into and form a part of it, as fully as if they had been expressly referred to or incorporated in its terms." 131 Those laws affect its construction as well as its enforcement or discharge. ${ }^{132}$ The freedom to contract itself is part of the law, and the law defines its scope and limits. This freedom preserves a considerable space for parties to create their own rules, but this space is still bounded by law. The freedom to contract, in this respect, is not different from royal prerogative. Both constitute part of the law, and both can only be exercised under the law, not above it.

Therefore, even though contractual restraints owe their origin to the purely private acts of the contracting parties, they present, from the rule of law perspective, the same questions that arise in the context of restraints imposed under royal prerogative, pursuant to a royal charter or a statutory grant, or in the disposal of one's property: can the person seeking to enforce the restraint show a valid legal basis for her alleged power to restrain another member of the community, and if she can, does the specific restraint lie within the scope of that power or exceed it? The scope of the various powers might

127 TREBILCOCK, supra note 28, at 5.

128 DiceY, supra note 15 , at 8.

129 Home Bldg. \& Loan Ass'n. v. Blaisdell, 290 U.S. 398, 429 (1934).

130 Norfolk \& W Ry. Co. v. Train Dispatchers, 499 U.S. 117, 130 (1991).

131 Id. at 129-30 (citing Farmers Bank v. Fed. Reserve Bank, 262 U.S. 649, 660 (1923)).

132 Farmers Bank, 262 U.S at 660. 
also be construed in light of the purpose for which the power was granted or recognized, and might also include the power to do things that are reasonably necessary to accomplish that purpose, but acts unrelated to that purpose, or that restrain more than is reasonably necessary to achieve it, might be considered beyond that scope.

That said, contracts in restraint of trade and restraints on alienation have presented courts with greater challenges compared to the questions surrounding the scope of statutory monopolies, because they involve a tension between two notions of freedom: freedom of contract and property and freedom of trade. ${ }^{133}$ Freedom of contract and property allows individuals to acquire property or dispose of it as they see fit and enter into binding contracts with others or arrange their affairs as they see fit. Protecting those freedoms requires the state to give them legal effect. Freedom of trade concerns the right of every member of the community to carry on any trade or business he chooses in such a manner as he thinks most desirable in his own interests. ${ }^{134}$ Freedom of trade entails that no one can lawfully interfere with another in the free exercise of his trade or business without a valid legal basis. ${ }^{135}$

On many occasions, those two freedoms support each other. Yet a private arrangement that enhances one party's or some parties' freedom may be seen as unduly restraining that of another party, and subjecting the latter party to arbitrary rules set by the former. Moreover, upholding the freedoms of one or some parties might interfere with those of third parties or the public at large, and some private arrangements that restrain trade may harm third parties and the public at large even while benefitting the contracting parties. ${ }^{136}$ In economic terms, the advantages of competition and freedom of trade and the cost of their absence are externalities, which contracting parties will rationally ignore. When freedom of contract and freedom of trade are misaligned, upholding freedom of contract may hinder freedom of trade, and promoting freedom of trade might require a limitation on freedom of contract. ${ }^{137}$

While these tensions have an economic dimension, they also represent a challenge for the rule of law. Recall that protecting individuals' rights is a central tenet of the rule of law, ${ }^{138}$ but which right should the law protect when

133 Nicola Giocoli, Free from What? Competition, Regulation and Antitrust During the Gilded Age 2 (Oct. 30, 2015) (unpublished manuscript), http://papers.ssrn. com/sol3/papers.cfm?abstract_id=2695362.

134 Fox, supra note 53, at 9.

135 Id.

136 See supra note 125 and accompanying text.

137 Giocoli, supra note 133, at 3.

138 Supra note 17 and accompanying text. 
the right to contract or the right to trade are misaligned? By prioritizing freedom of contract courts in such cases may allow one (powerful) party (or a group of parties) to subject others to a set of privately promulgated rules, which may be just as arbitrary and harmful as those imposed by public officials who yield unconstrained state power. In other words, freedom of contract in such cases may allow private actors effectively to assume unbridled lawmaking powers. If so, then the public interest in curtailing such powers may encompass not only the benefit of competitive markets, but also the broader public interest in a political order where one person is not subject to the whims of another. If the rule of law means the supremacy of law, the rule of law ought to constrain all types of arbitrary power, public and private alike.

Indeed, seventeenth century lawyers figured that state-imposed restraints and privately created ones may "differ only in this, that the first is by patent from the King, the other by act of the subject, between party and party; but both are equally injurious to trade and the freedom of the subject, and therefore equally restrained by the common law." 139 The case law from that period likewise routinely invoked all of those dimensions, the economic and the constitutional; restraints on trade were considered injurious to trade as they were inimical to the liberty of the subject.

However, by the middle of the nineteenth century (and in the United Kingdom well into the twentieth century) the courts would treat restraints imposed by public officials or by non-state entities exercising regulatory powers very differently from restraints imposed by private entities in commercial settings. Rule of law considerations continued to play an important role in the first type of cases, ${ }^{140}$ but they ceased to play any important role in contractual restraint

139 A statement by Sir Francis Bacon, cited in Fox, supra note 53, at 21 n.6, and Malament, supra note 55, at 1345.

140 For example, in Gosling v. Veley (1852-53) 4 H.L.C. 679, a church-imposed levy on parishioners for church repairs was challenged for being without legal authority. By law, the levy was required to be put to a vote of the parishioners, which it had been, but the majority of those voting had voted against it. Regardless, the vicar, the churchwardens and a small minority of parishioners attempted to institute it. The House of Lords held the levy to be invalid on the basis that no pecuniary burden could be imposed except under a clear and distinct legal authority, which the vicar and churchwardens in this case failed to provide. Similarly, in London \& Brighton Ry. Co. v. Watson [1878] 3 C.P.D. 429, 43435 (Div. Ct.), aff'd, [1879] 4 C.P.D. 118 (C.A.), a bylaw of a railway company imposing a financial penalty on those riding without tickets was held to be invalid on the basis that the statute empowering the railway to create bylaws allowed for the creation of such bylaws only in accordance with that statute. The statute itself imposed a penalty for nonpayment of fares only in cases of fraud. As the 
of trade cases. ${ }^{141}$ Laissez faire attitudes also influenced the approach to the exercise of IP rights and IP owners' ability to impose post-sale restraints. Many courts not only held that contractual restraints would generally be valid, but also allowed IP owners to impose enforceable post-restraints on those having mere notice of them. ${ }^{142}$ U.S. courts were initially inclined to follow the British approach, but after the passage of the Sherman Act in $1890^{143}$ the American courts began to reverse course. The next Parts describe American courts' newfound interest in broader questions surrounding the limitations on private and delegated power, and how these questions shaped the development of both IP and antitrust law.

\section{Antitrust, Nondelegation and Due Process}

The enactment of the Sherman Act in the United States in 1890 (and competition legislation in Canada, Australia, and New Zealand around that time) was one of the signals that the laissez-faire era was reaching its end. ${ }^{144}$ Technological and organizational factors contributed to a growing concentration of wealth and power during the "gilded age," but they also contributed to the growth and sophistication of local and central government and revived political interest in rebalancing freedom of contract and freedom of trade. The legitimation of trade unions, the passage of legislation governing labor conditions, the enactment of basic consumer protection legislation, food and drug regulation, and other reforms associated with the "progressive era" rekindled the interest in questions surrounding the limitations on state power, private power, and delegated power.

bylaw imposed the penalty for nonpayment regardless of whether the rider had committed fraud, it legislated in a manner going beyond the empowering statute, and was thus void. Further, in Attorney General v. Wilts United (1921) 37 T.L.R. at 886 (C.A.), aff'd, (1922) 38 T.L.R. 781 (HL), a levy imposed by the administrative Food Controller on milk sales as a condition for the grant of a license to purchase and distribute dairy products was held to be invalid on the basis that the statutory authority granted to the Food Controller allowed for the regulation of milk sales, but not expressly the imposition of what was deemed to be a tax. The court held that clear Parliamentary authority for such a levy must be shown in the empowering act for the levy to be valid.

141 See supra notes 110-119 and accompanying text.

142 See, e.g., Nat'l Phonograph Co. of Austl. v. Menck (1911) 12 C.L.R. 15 (PC) (appeal taken from Austl.).

143 Sherman Act, 26 Stat. 209, 15 U.S.C. §§ 1-7 (1890).

144 TREBILCOCK, supra note 28, at 29. 
Despite the dominance of economic analysis and reasoning in contemporary antitrust law, as a product of the progressive era, constitutional, or rule of law, considerations shaped the development of antitrust law during its formative years, and they have also impacted the development of IP law in the United States. Such considerations, invoking similar concerns to those expressed by seventeenth century jurists, permeate many of the seminal judicial decisions of the era - sometimes impliedly, but often explicitly. ${ }^{145}$ As Nachbar has shown, economic efficiency analysis cannot explain some aspects of antitrust law. Instead, far from being singularly focused on increasing output and efficiency, antitrust law has played an additional constitutional role of maintaining distinctions between public and private power. To ensure that private actors do not assume regulatory powers - the grant and exercise of which is the province of the state - has been an important goal of antitrust laws. According to Nachbar, antitrust law seeks to prevent two distinct types of harms: the familiar "market harm," described and measured as a harm to efficiency, but also a "regulatory harm" — harm to the freedom of choice felt by those participating in the market. ${ }^{146}$ Antitrust law is not merely a rule of economic regulation, but also a rule against private regulation. ${ }^{147}$

Two examples that illustrate this point most clearly are Addyston Pipe \& Steel v. United States, ${ }^{148}$ and Fashion Originators' Guild of America v. FTC. ${ }^{149}$ Addyston Pipe involved a cartel among iron pipe manufacturers. The Sixth Circuit held that the agreement violated the Sherman Act, ${ }^{150}$ and on appeal to the Supreme Court, the companies attacked the validity of the Act itself, arguing that the Commerce Clause did not empower Congress to prohibit private agreements but only to remove state-made barriers to interstate commerce. The Court rejected the argument. It characterized the agreement between the companies as "regulation of commerce among the States," and added that such private regulation by contract, if sustained, could be just as effective as regulation by the state. ${ }^{151}$ If, the Court reasoned, "a State, with its recognized power of sovereignty, is impotent to obstruct interstate commerce," then a fortiori a "mere voluntary association of individuals within the limits of that

145 Nachbar, supra note 6.

$146 I d$. at 69.

$147 \mathrm{Id}$.

148 Addyston Pipe \& Steel Co. v. United States, 175 U.S. 211 (1899).

149 Fashion Originators' Guild of Am. v. FTC, 312 U.S. 457 (1941).

150 United States v. Addyston Pipe \& Steel Co., 85 F. 271 (6th Cir. 1898). The Sixth Circuit's decision is important for additional reasons discussed below. See infra notes 304-309 and accompanying text.

151 Addyston, 175 U.S. at 230. 
State [could not have] a power which the State itself does not possess."152 In other words, the vice of the agreement was not its impact on economic efficiency, but the arrogation, by the participating companies, of regulatory powers that only Congress could exercise.

The Fashion Originators ' Guild case involved an attempt by a large group of apparel and textile makers to create and enforce a private intellectual property protection system for their designs. To be effective, the system required not only that the guild members adhere to the rules, but also measures preventing retailers from selling garments made by nonmembers. The problem, Nachbar explains, "went beyond the obvious competitive harms (such as the reduction in the number of outlets for apparel)."153 The real problem was that the Court viewed the Guild as "in reality an extra-governmental agency, which prescribes rules for the regulation and restraint of interstate commerce, and provides extra-judicial tribunals for determination and punishment of violations, and thus 'trenches upon the power of the national legislature and violates the statute." "154

Nachbar tied his analysis to the American "nondelegation doctrine." $155 \mathrm{He}$ maintains that notwithstanding debates on whether the doctrine still effectively

152 Id. (quoting In re Debs, 158 U.S. 564, 581 (1895)).

153 Nachbar, supra note 6, at 93. While Nachbar asserted that the competitive harms were obvious, they might not appear obvious at all for a contemporary economically oriented analyst. Rob Merges, for example, has criticized the Court's noncompromising condemnation of the Guild. Robert P. Merges, Contracting into Liability Rules: Intellectual Property Rights and Collective Rights Organizations, 84 CALIF. L. Rev. 1293, 1364-66 (1996). Not only did he question the existence of market harm, id. at 1365, but he also claimed that the Guild members' private IP regime might have been efficient, and possibly even more efficient than formal IP systems, id. at 1364. In his view, the Court should have bifurcated the issues in the Fashion Originators' Guild case, condemning practices such as price fixing, but remanding the case with instructions to find facts regarding the efficacy and economic impact of the basic anti-copying arrangement. $I d$. The Court should have considered whether the Guild tended to enhance economic efficiency, and whether it did so at a lower cost than a formal property right in dress designs. Id.

154 Fashion Originators' Guild, 312 U.S. at 463-65 (quoting Addyston, 175 U.S. at 242); accord Nachbar, supra note 6, at 93.

155 The American nondelegation doctrine stems from Const. art. 1, $\S 1$, whereby Congress is vested with "all legislative powers." Taken literally, it would mean that Congress could not delegate any lawmaking authority. It was held, however, that Congress could delegate legislative authority to the executive branch so long as it provides an "intelligible principle." See J.W. Hampton, Jr. \& Co. v. United States, 276 U.S. 394, 409 (1928). 
exists, the doubts apply only with respect to legislative delegations to public administrative agencies. Conversely, the prohibition against delegations of regulatory authority to private actors "is so ingrained in constitutional law as to go almost unnoticed." 156

In another recent article, The New Private-Regulation Skepticism, Alexander Volokh has discussed how, in addition to the nondelegation doctrine and antitrust, the "private due process" doctrine has also been used to limit the delegation of coercive power to private parties. ${ }^{157}$ The key example he provides is Eubank $v$. City of Richmond, ${ }^{158}$ a case involving a city ordinance (and the statute under which it was adopted) that allowed the owners of two-thirds of the property abutting a street to establish a "building line" beyond which construction would be illegal. ${ }^{159}$ The Supreme Court held that the ordinance and the statute violated due process, because they allowed one set of property owners to determine not only how they use their property, but also the kind of use which another set of owners may make of their own property. The legislation conferred the power on some property holders to virtually control and dispose of the property rights of others, without providing any standard by which the power is to be exercised. The grant of such unbounded powers, which could be used solely for the grantees' own interest or even capriciously, was the vice of the legislation and made it an unreasonable exercise of the police power. ${ }^{160}$

A few years later, however, in Thomas Cusack Co. v. City of Chicago, the Supreme Court upheld a municipal ordinance that prohibited the erection of billboards without first obtaining the consent of a majority of the property fronting the street. ${ }^{161}$ For constitutional purposes, the difference in the baseline was crucial. ${ }^{162}$ In Cusack, the legislator itself created the limitation on the use of private property, which it was empowered to do. The legislation only delegated to a majority of property owners the power to lift the limitation. In Eubank, however, the legislation purported to delegate to private individuals an unconstrained legislative power to limit the rights of others. ${ }^{163}$ In Eubank, the Court was concerned that such delegated power could be used arbitrarily or to advance ulterior goals. In Cusack, the Court did not think that such a

156 Nachbar, supra note 6, at 81 .

157 Alexander Volokh, The New Private-Regulation Skepticism: Due Process, Non-Delegation, and Antitrust Challenges, 37 Harv. J.L. \& Pub. PoL'y 931, 941 (2014).

158 Eubank v. Richmond, 226 U.S. 137 (1912).

159 Volokh, supra note 157 , at 941.

160 Eubank, 226 U.S. at 143-44.

161 Thomas Cusack Co. v. City of Chicago, 242 U.S. 526, 527 (1917).

162 Volokh, supra note 157, at 942.

163 Cusack, 242 U.S. at 531. 
danger existed, because the exercise of the delegated power could not harm the petitioner, and could only benefit it. ${ }^{164}$

The distinction between Eubank and Cusack is reminiscent of both the distinction and the affinity between the power to make laws and the power to dispense with the operation of laws. As noted above, struggles around the scope of royal prerogative concerned both, and those struggles resulted in the limitation of both. ${ }^{165}$ And indeed, several years after Cusack, the Court invalidated a Cusack-like city ordinance on Eubank-like grounds. At issue in Washington ex rel. Seattle Title Trust Co. v. Roberge, ${ }^{166}$ was a municipal zoning ordinance that conditioned the building of a philanthropic home for children or for old people in a residential district on obtaining the written consent of the owners of two-thirds of the property within four hundred feet of the proposed building. ${ }^{167}$ The Court distinguished Cusack on the basis that the regulation in Cusack sought to prohibit a public nuisance, whereas there the building of a philanthropic home was found to be harmonious with the zoning goals. That being established, the Court faulted the ordinance for purporting to give the property owners the untrammeled power to prevent the petitioner from using its land for the proposed home. There was no provision for review under the ordinance, and it gave the property owners the final authority to decide. Not bound by any official duty, the property owners were "free to withhold consent for selfish reasons or arbitrarily and may subject the [petitioner] to their will or caprice." 168

Volokh and to some extent Nachbar frame the constitutional law questions as capital-C constitutional questions, that is, as questions of constitutional rights or principles derived from written constitutional documents. As capital-C constitutional doctrines, whether they apply in particular cases depends on the fine details of those doctrines as laid down in the case law, and in any event they have no direct equivalence under the Westminster tradition of Parliamentary sovereignty, and in this regard are very different from the series of English cases discussed above. However, small-c constitutional law considerations, which Lisa Austin describes as the "the core ideas that law cannot confer the authority to exercise power arbitrarily and that law must be able to guide actions," 169

164 Id. at 530.

165 See supra Part II.

166 Washington ex rel. Seattle Title Tr. Co. v. Roberge, 278 U.S. 116 (1928).

167 Id. at 118.

168 Id. at 122.

169 Lisa M. Austin, Technological Tattletales and Constitutional Black Holes: Communications Intermediaries and Constitutional Constraints, 17 THEORETICAL INQUIRIES L. 451, 452 (2016). 
have a much wider application. These principles have been used in all common law jurisdictions to invalidate subordinate legislation, narrow its reach, as well as to favor a narrower construction of statutes over an equally plausible broader one. ${ }^{170}$ In that sense they function like what Cass Sunstein described as "hidden nondelegation principles," 171 and they also comport with other canons of construction, such as the principle that legislative intent to depart from common law principles must be communicated with irresistible clarity, ${ }^{172}$ or the principle that statutory grants that derogate from the common law rights of others ought to be construed narrowly. ${ }^{173}$

170 See supra note 140; see also Can. Broad. Corp. v. SODRAC 2003 Inc., 2015 SCC 57, [2015] 3 S.C.R. 615 (Can.). In Canadian Broadcasting Corp., the Supreme Court of Canada rejected the view that users of copyrighted works were automatically bound by the terms and conditions of copyright licenses determined by the Copyright Board. The Court stated that the conclusion that those licenses are not binding on users comports with the more general legal principle that 'no pecuniary burden can be imposed upon the subjects of this country, by whatever name it may be called, whether tax, due, rate or toll, except upon clear and distinct legal authority': Gosling v. Veley (1850), 12 Q.B. 328, 116 E.R. 891, at p. 407, as approved and adopted in Ontario English Catholic Teachers' Assn. v. Ontario (Attorney General), 2001 SCC 15, [2001] 1 S.C.R. 470, at para. 77, and Attorney-General v. Wilts United Dairies, Ltd. (1921), 37 T.L.R. 884 (C.A.), at p. 885 . . . In the absence of clear and distinct legal authority showing that this was Parliament's intent, the burdens of a licence should not be imposed on a user who does not consent to be bound by its terms.

Id. $\uparrow 107$.

171 Cass R. Sunstein, Nondelegation Canons, 67 U. CH. L. Rev. 315 (2000) (discussing various hidden nondelegation principles reflected in various canons of statutory interpretation).

172 E.g., Goodyear Tire \& Rubber Co. of Canada v. T. Eaton Co., [1956] S.C.R. 610 (Can.); United States v. Texas, 507 U.S. 529, 534 (1993).

173 See, e.g., Theodore Sedgwick, A Treatise on the Rules Which Govern the Interpretation and Construction of Statutory and Constitutional Law 29192 (John Norton Pomeroy ed., Baker, Voorhis \& Co. 2d ed. 1874). Sedgwick explains that unlike the civil law that is inclined to consider grants made by the sovereign with a favorable eye, the common law,

in obedience to its instinctive sympathy with equal rights and its jealousy of prerogative, has always adopted a widely different and much sounder rule. The uniform language of the English and American law is that all grants of privilege are to be liberally construed in favor of the public, and as against the grantees of the monopoly, franchise, or charter to be strictly interpreted. Whatever is not unequivocally granted in such acts, is taken to have been withheld.

Id. 
Very similar constitutional issues have arisen in a series of foundational American IP cases decided since the early decades of the twentieth century. Just as antitrust law has not been singularly focused on maximizing output and efficiency or any other economic goal, IP law is not solely occupied with such goals as optimizing tradeoffs between long-term dynamic efficiency gains and short-term static efficiency losses, and important elements of IP doctrine reflect concerns about the proper division of regulatory powers between private actors and state actors. The next Part exposes those features.

\section{Extending the Monopoly}

Between 1908 and 1918 the U.S. Supreme Court decided a series of cases concerning various attempts by owners of patents and copyrights to rely on their IP rights to impose downstream restrictions on the resale or use of copyrighted works or patented articles. ${ }^{174}$ For the most part, the Court declined to interpret the IP statutes as conferring such powers. ${ }^{175}$ These cases gave rise to the first sale doctrine (or exhaustion), formed the basis of the IP misuse doctrine, and, even though none of them was decided on the basis of antitrust law, they also influenced antitrust law's approach to resale price maintenance and tying arrangements. ${ }^{176}$

During the last fifty years, however, some law and economics scholars have questioned the validity of the reasoning of those cases, and their criticism has wielded enormous influence, especially on the development of antitrust law and competition economics. They have criticized the Court for employing bad economics, and pointed out that many of the practices that the Court had condemned might be, and often are, efficient. ${ }^{177}$ However, as I demonstrate below, this criticism has often misunderstood the Court's reasoning and ignored the fact that the Court's decisions were not focused on applying economic principles but on protecting the rule of law. The Court did not invalidate the various practices because it perceived them as economically harmful, but because it considered the legal theories behind the attempts to impose and enforce the restraints as legally untenable.

This Part focuses on the cases involving the tying of non-patented articles to the sale of patented devices, and the Court's view that they involved impermissible attempts to "extend the monopoly" of the patent owner. This

174 See infra Section V(C).

175 See infra Section V(C).

176 Herbert Hovenkamp, Post-Sale Restraints and Competitive Harm: The First Sale Doctrine in Perspective, 66 N.Y.U. AnN. Surv. Am. L. 487, 508 (2010-2011).

177 Katz, supra note 125, at 71. 
reasoning has been the main target of the law and economics criticism. In a seminal article from 1957, Ward Bowman argued that monopolists cannot generally extend or "leverage" their monopoly from one market to another through product tying, and that in many cases tying can actually be a socially efficient business practice that ought not to be condemned. ${ }^{178}$ Bowman was building on an earlier paper by Aaron Director and Edward Levi, where they introduced what has become known as the "single monopoly profit theory."179 As Einer Elhauge explains in his critique of the single monopoly profit theory, it holds that, generally, "a firm with a monopoly in one product cannot increase its monopoly profits by using tying to leverage itself into a second monopoly in another product." ${ }^{180}$ On the basis of that theory, Bowman criticized those rulings for having "been based upon an imprecise evaluation of the economic effects of tying practice in extending monopoly."181

In his 1973 book, Patent \& Antitrust Law: A Legal \& Economic Appraisal, Bowman singled out Justice Clarke's reasons in Motion Picture Patents $v$. Universal Film ${ }^{182}$ from 1917 as the signpost that misdirected the development of the law. He described the decision as having been based on a "leveraging fallacy" and lamented that the fallacy was accepted as gospel:

Were [the leveraging argument] true, as succeeding justices assumed, much of the subsequent law would have been unobjectionable. But by parlaying a leverage fallacy with an unproved, incipient monopoly hypothesis (arising from an assumed identity between effect on competitors and effect on competition) the Court has since 1917 consistently applied faulty economics leading to the wrong answers to the questions it has asked. ${ }^{183}$

Challenging the notion that patent law and antitrust promote conflicting goals, he stated, in what has become a mantra, that the two laws actually share a single, common goal — "to maximize wealth by producing what consumers want at the lowest cost." 184 This view implied that patentees' efforts to appropriate as much as possible of the surplus of the patented invention,

178 Ward S. Bowman, Jr., Tying Arrangements and the Leverage Problem, 67 Y ALE L.J. 19 (1957).

179 Aaron Director \& Edward H. Levi, Law and the Future: Trade Regulation, 51 Nw. U. L. Rev. 281, 290 (1956).

180 Einer Elhauge, Tying, Bundled Discounts, and the Death of the Single Monopoly Profit Theory, 123 HaRv. L. REv. 397, 403 (2009).

181 Bowman, supra note 178, at 34.

182 Motion Picture Patents Co. v. Universal Film Co., 243 U.S. 502 (1917).

183 Bowman, supra note 2, at 182.

184 Id. at 1 . 
i.e., its social value in excess of marginal cost, should not be condemned but encouraged. The message was not only that such efforts, which were to be accomplished through a variety of practices such as tying, do not generally harm competition, but the potential for appropriating as much rents as possible also provides the engine that drives innovation. ${ }^{185}$

From this economic perspective (overly simplistic - theoretically and empirically — as it may be ${ }^{186}$ ), the Court's decisions, inasmuch as they make it more difficult for patentees to maximize rent appropriation, would appear flawed. But as the analysis below shows, Justice Clarke and the other justices concurring with him did not ask economic questions and did not apply economic theory - faulty or sound - in answering them. Rather, they asked legal questions and applied constitutional principles to solve them.

\section{A. Tying Cases: Motion Picture Patents Co. v. Universal Film}

In the Motion Picture Patents case, the paragon of Bowman's criticism, the plaintiff, the Motion Picture Patents Company, sought relief against the three defendants as joint infringers of one of its patents. The patent, granted for improvements in projecting-kinetoscopes, covered a part of the mechanism used in motion picture exhibiting machines for feeding a film through the machine with a regular, uniform, and accurate movement, and so as not to expose the film to excessive strain or wear. ${ }^{187}$ The defendants were not competing manufacturers of machines but rather users of those machines. Not only were they users, they were also licensed users, and so the allegation of infringement pertained to the use of the patented machine in breach of some of the terms of the license.

The machines themselves were not manufactured or sold by the plaintiff, but by its licensee, the Precision Machine Company. The license agreement required Precision to sell any machine under terms, which among others, limited the use of the machine solely to exhibiting or projecting motion pictures leased from a licensee of the plaintiff (the plaintiff owned a separate patent covering the compatible motion pictures). Those terms were also stated in a plate affixed to every machine, which further stated that its removal or defacement would terminate the right to use the machine. ${ }^{188}$ The Court

185 See F.M. Scherer, Conservative Economics and Antitrust: A Variety of Influences, in How the Chicago School Overshot the Mark: The Effect of Conservative Economic Analysis on U.S. Antitrust 30, 38-39 (Robert Pitofsky ed., 2008).

186 Id.

187 Motion Picture, 243 U.S. at 505.

$188 \mathrm{Id}$. at 506-07. 
framed the issue before it as "the extent to which a patentee or his assignee is authorized by our patent laws to prescribe by notice attached to a patented machine the conditions of its use and the supplies which must be used in the operation of it, under pain of infringement of the patent." 189 In other words, the Court framed the question purely as a legal one: the scope of the legal powers that the grant of a patent confers upon the patentee and that the court will enforce.

The Court did not ask, and therefore did not answer, whether it would be efficient to allow patentees to impose the particular restraints. The Court was not totally oblivious to the possible economic benefits of the tying restriction. The plaintiffs argued that the tying arrangement benefits the public because it allows them to sell at cost and then profit from the sale of the tied supplies. But the Court did not reject the argument because it disagreed with its economics, but because it only proved "that under color of its patent the owner intends to and does derive its profit, not from the invention on which the law gives it a monopoly," but from controlling and raising the prices of the unpatented supplies over which it had no patents. ${ }^{190}$ The vice in the plaintiff's practice and in the legal theory it relied on was the attempt to use the patentee's legal power to control one specific area - its invention - to restrain trade in other products. This attempt was invalid, not because it was inefficient, but because it lacked legal basis, as it purported, without statutory warrant, to control activities over which the plaintiff had never been granted a monopoly. ${ }^{191}$

The following points further underscore the fact that the Court focused on rule of law questions - delineating the boundary of the legal powers that the patent statute confers upon the patentee. The Court emphasized that the case involved a claim of infringement of a patent, and therefore it was not concerned with the extent to which a special contract between the owner of a patent and the purchaser or licensee might validly require the use of specific supplies. ${ }^{192}$ Nor did it have to decide whether an owner of a machine might be able, under the general law, to control the materials used in operating it. The crucial point was that such powers could not be derived or protected by the patent law. ${ }^{193}$

$189 \mathrm{Id}$. at 509.

$190 \mathrm{Id}$. at 517.

$191 \mathrm{Id}$. at 518.

$192 I d$. at 509.

$193 \mathrm{Id}$. at 513. The Court, however, did not imply that as a matter of general law ownership of a machine necessarily entails such powers, or that a contractual restraint would be valid. See infra note 288. 
Lastly, the Court acknowledged the passage of the Clayton Act three years earlier, which declared practices such as those at issue unlawful, where their effect "may be to substantially lessen competition or tend to create a monopoly in any line of commerce," 194 but noted that even though the enactment contained "a most persuasive expression of the public policy of our country with respect to the question before us" it was unnecessary to decide whether the case involved an antitrust violation as well. ${ }^{195}$

Focusing on the question of the patentee's power under the patent laws, the Court concluded that the restrictions were invalid

because [the] film is obviously not any part of the invention of the patent in suit; because it is an attempt, without statutory warrant, to continue the patent monopoly in this particular character of film after it has expired, and because to enforce it would be to create a monopoly in the manufacture and use of moving picture films, wholly outside of the patent in suit and of the patent law as we have interpreted it. ${ }^{196}$

I do not wish to quarrel with Bowman's economic insights. Although not unassailable, ${ }^{197}$ he persuasively demonstrated various reasons why manufacturers would seek to impose tying restrictions, why such restrictions might be efficient, and why they could not necessarily be used to leverage a firm's dominance in one market into another. Bowman's article, Tying Arrangements and the Leverage Problem, ${ }^{198}$ has been one of the most cited articles in the history of the Yale Law Journal, ${ }^{199}$ and its influence on the development of antitrust law has been undoubtedly enormous. Not much credit, however, can be given to the carelessness of the legal analysis displayed in that article. For example, the article opens with the following statement: "In antitrust law, the conclusion that tying the sale of a second product to a patented product is automatically illegal has been accepted by courts for forty years," 200 and the supporting footnote states that the rule was established in Motion Picture. ${ }^{201}$

194 Clayton Act, 15 U.S.C. $§ 14$ (2012).

195 Motion Picture, 243 U.S. at 517-18.

196 Id. at 518.

197 For a critique of the single monopoly profit theory, see Elhauge, supra note 180. See also Dennis W. Carlton \& Michael Waldman, Robert Bork's Contributions to Antitrust Perspectives on Tying Behavior, 57 J.L. \& Econ. S121 (2014); Scherer, supra note 185.

198 Bowman, supra note 178.

199 Fred R. Shapiro, The Most-Cited Articles from the Yale Law Journal, 100 YALE L.J. 1449 (1991).

200 Bowman, supra note 178, at 19.

201 Id. at 19 n.1. 
But as noted above, the Court in Motion Picture consciously decided the case on the basis of patent law alone, and therefore that case did not establish and could not establish any antitrust rule.

Bowman was first and foremost an economist, ${ }^{202}$ and regardless of whether his analysis of the effects of tying arrangements is sound as a matter of economic theory, his discussion and critique of the law is based on a complete misreading or misunderstanding of the Court's legal reasoning. In a nutshell, he failed to recognize that the term "monopoly" carries with it two meanings: one economic and legally specific in antitrust law, and another strictly legal.

As an economist, Bowman read the word "monopoly" as denoting the economic meaning that it carries in modern antitrust law. He explained: "Monopoly is commonly described as the power to set a price." ${ }^{203}$ In this sense, monopoly is synonymous with "market power." 204 Thus, he interpreted the Court's conclusion in Motion Picture that enforcing the patentee's scheme would result in "a monopoly in the manufacture and use of moving picture films, wholly outside of the patent in suit," ${ }^{205}$ as a statement about the economic impact of the tying arrangement and a conclusion that the tying arrangement would allow the patentee to leverage its market power from one market to another. Thus understood, he went on to note that whether a monopolist could leverage its market power from one market to another by tying depends on whether the tie leads to reduced output of the tied product. ${ }^{206}$ If the tying arrangement cannot reduce output in the market for the tied product, no second monopoly in that market can be created. ${ }^{207}$ Not only is this an empirical question that needs to be proven, and ought not to be assumed, it is more likely that tying could be used for efficient, pro-competitive purposes than for anti-competitive purposes. Therefore, he concluded, the Court's disapproval of the tying was based on false economics and needed to be reevaluated. ${ }^{208}$

202 Bowman gave credit to John S. McGee, then an Associate Professor in the School of Business at the University of Chicago, for jointly developing some of the economic insights of the article, being a substantial contributor to the analysis in it, and reading and criticizing the manuscript in several drafts. Id. But McGee, like Bowman, was an economist, not a legal scholar.

203 Id. at 20 n.5.

204 See generally Ariel Katz, Making Sense of Nonsense: Intellectual Property, Antitrust, and Market Power, 49 Ariz. L. Rev. 837 (2007).

205 Motion Picture Patents Co. v. Universal Film Co., 243 U.S. 502, 518 (1917).

206 Bowman, supra note 178, at 20.

207 Id.

208 Id. Interestingly, Bowman suggested that the tying arrangement in the Motion Picture case might have been anticompetitive, but since the Court had not really 
If the Court's unwillingness to enforce the tying arrangement was based on a theory of market-power leverage, then Bowman's criticism was in place. However, the Court based its ruling on entirely different grounds. It did not use the term "monopoly" the way modern antitrust lawyer-economists use it, but only in its general and long-standing legal sense and the one often employed in IP law. As discussed above, dating back at least to the first half of the sixteenth century, the term "monopoly" describes the grant of various commercial and industrial privileges to individuals or companies. ${ }^{209}$ This is the meaning that the Court used in Motion Picture and other contemporaneous cases - a meaning that was clearly understood at the time. For example, in Bauer \& Cie. v. O'Donnell the Court noted that "[ $\mathrm{t}]$ he right to make, use, and sell an invented article is not derived from the patent law. This right existed before and without the passage of the law, and was always the right of an inventor." 210 What the grant of a patent does, however, is secure "to the inventor the exclusive right to make, use, and vend the thing patented, and consequently to prevent others from exercising like privileges without the consent of the patentee." 211 The scope of those exclusive rights defines the "extent of the patent monopoly under the statutes of the United States." 212 In United States v. Motion Picture Patents Co., a criminal antitrust case against the company brought by the government and was litigated in parallel to the company's attempts to enforce its patents, the district court made the same point in even starker terms:

As has been well said, the patent laws do not confer any right to make, use, or vend the subject-matter of an invention. This is the natural right of the inventor. What the patent law does do, for one thing, is to take away, for a limited time, from all others than the patentee, or his assigns, that which would otherwise have belonged to them also - the right to make, use, or vend the patented article. Another thing it does is to proffer to the patentee the aid of the law in enforcing this prohibition upon others. The latter is really the right given. . . This is, in a very substantial sense, a monopoly. ${ }^{213}$

In the civil Motion Picture patent case the Court expounded on those propositions. After explaining that the only effect of a patent is to restrain others

considered the economic effects, the right result might have been reached for the wrong reasons. $I d$. at 20.

209 See supra Section II(A).

210 Bauer \& Cie. v. O’Donnell, 229 U.S. 1, 10 (1913).

211 Id.

$212 \mathrm{Id}$. at 11.

213 United States v. Motion Picture Patents Co., 225 F. 800, 804 (E.D. Pa. 1915). 
from manufacturing, using, or selling that which the patentee has invented, the Court stated: "The patent law simply protects him in the monopoly of that which he has invented and has described in the claims of his patent."214 The "monopoly" that the Court was talking about was the legal monopoly - the right to restrain others from practicing the invention as defined in the claims of the patent. The Court then emphasized that "the primary purpose of our patent laws is not the creation of private fortunes for the owners of patents," 215 but, pursuant to the Constitution, "to promote the progress of science and the useful arts." 216 It reiterated earlier holdings emphasizing that "the primary object" of granting patents was "the benefit to the public or community at large," not the inventors " "exclusive profit or advantage." ${ }^{217}$ It finally concluded that "[t]hese rules of law make it very clear" that the patentee has only the powers that were specifically granted to him by Congress, and the exercise of those powers must be limited to the invention described in the claims of his patent and not beyond them. ${ }^{218}$

In other words, as a matter of law the plaintiff's patent - his legal monopoly - only gives him powers pertaining to the subject matter described in the claims of the patent. In the present case, the patent concerned an invented machine, and therefore gave the plaintiff only the "exclusive right to use the mechanism to produce the result with any appropriate material." ${ }^{219}$ The plaintiff did not invent and his patent did not cover "materials with which the machine [could be] operated [and therefore were] no part of the patented machine or of the combination which produces the patented result." ${ }^{220}$ Therefore, the law allowed the patentee to impose only restrictions that relate to the useful and novel features of the machine as described in the claims of the patent, and since those legal restrictions had nothing to do with the materials used in the operation of the machine, the patentee lacked the legal power to impose them. ${ }^{221}$

It should now be clear that the Court insisted that the patentee's power to legally control the activities of others - its legal monopoly - cannot extend beyond the scope of his invention as described in the claims, and that this monopoly does not confer any power to restrain others from doing things falling beyond the scope of the claims of the patent. The Court was not

214 Motion Picture Patents Co. v. Universal Film Co., 243 U.S. 502, 510 (1917).

$215 \mathrm{Id}$. at 511.

216 Id.

217 Id.

218 Id.

$219 \mathrm{Id}$. at 512.

$220 \mathrm{Id}$.

221 Id. 
applying any faulty economic analysis, as Bowman alleged, because it was not applying any economic analysis at all. Rather, it was deciding on the basis of legal principles, invoking established "rules of law." 222 It reasoned that as a matter of law, the patentee can only restrain others from using his invention as defined in the claims of the patent, and cannot extend those restrictions to acts that extend beyond the claims of the patent. Holding otherwise would run afoul of the rule of law because it would allow the patentee to enlist the coercive power of the state - through the courts - to restrain others from doing things that the common law entitles them to do. In effect, it would endow the patentee with wide and unconstrained power to affect the rights of others, turning the patentee into a legislator. In sum, Motion Picture was a ruling applying the rule of law, not a ruling purporting to decide whether a particular business practice was efficient.

\section{B. The Dual Meaning of "Monopoly"}

In the previous Section I showed that in Motion Picture and other contemporaneous cases the courts used the term "monopoly" in its legal sense, not in its modern antitrust sense. In this Section I show that the courts at the time appear to have been fully cognizant of the difference between the two, but also of the possibility that the two could be interconnected. For example, in the separate antitrust criminal case against the Motion Picture Patent Company, mentioned above, the district court, after explaining why a patent is a monopoly (in the legal sense), immediately proceeded to explain the difference between monopoly in that sense and monopoly for the purposes of the antitrust laws. "It must be, however," the court clarified, "that the monopoly [granted under the patent act] is not the monopoly condemned by the [Sherman] act of $1890^{\prime 2} 23$ — first, because a patent can only be granted to something that did not exist before, and therefore its grant could not be said to restrain or monopolize a trade which has no existence; and second, because "a monopoly created by law, in pursuance of a policy of the law, cannot be said to result from such restraint" which the Sherman Act prohibits. To hold otherwise would be absurd. ${ }^{224}$

But to recognize that the term monopoly, as used in antitrust law, carries with it a different meaning than the one it has elsewhere in the law and in patent law does not mean that the use of the same term in antitrust law and in patent law reflects a mere semantic coincidence or, worse, an enduring and

222 Id. at 511.

223 United States v. Motion Picture Patents Co., 225 F. 800, 804-05 (E.D. Pa. 1915).

224 Id. 
persistent misunderstanding, as some have argued. ${ }^{225}$ It is only because of the recent triumph of the view that antitrust law has only a single and economic goal that the two meanings appear to be entirely unrelated. However, until that view became the gospel of the current orthodoxy, the duality of the meaning of the term "monopoly" in its legal and political sense and its antitrust economic sense was well understood. Courts and commentators appreciated not only the differences between the two meanings but also their interconnectedness. They understood the difference between economic power and political power, but they also recognized that the two may feed each other.

Consider, for example, the following passage from the Motion Picture criminal antitrust case, mentioned above, which situated the case in a particular legal-political-constitutional context:

At the risk of being open to the criticism of its being wholly academic, a start may be made with a few general observations. The beginnings of this controversy are found in the ages-long struggle "to secure the blessings of liberty," to obtain which is stated to be one of the objects of our Constitution. There is deep-grained in human nature the impulse to influence, and, so far as it can be done, control, the actions of others. It is too much to expect that this control, when secured, will always be exerted for altruistic ends. Out of this condition has arisen the need of a power of government to check the restraints which the strong would otherwise impose upon those whom they could control. Power and efficiency, however, are possessed in insensible gradation, and there is a right to the liberty of its full, fair exercise. There would be no real gain in securing to some freedom from extralegal control, by imposing upon all unfair and unreasonable restraint, through an unfair and unwise administration of the law.

The liberty spoken of in our Constitution had more direct reference to this latter freedom from the 'undue and unreasonable' exactions of constituted rulers. In the cycle of human effort, we have come back to the needs which moved men into constituting rulers over themselves, and the power of the law has been invoked for protection against what are declared to be evil practices. The particular phase of liberty with which this [antitrust] law concerns itself is the freedom or free flow of commerce. It is based upon the right of every individual to choose his own calling in life, and to follow the trade of his choice unhampered by any undue and unfair interference from others. It secures this "blessing of liberty" to all by making it unlawful for any to conspire to bring

225 Katz, supra note 204. 
about "restraint of trade or commerce." This is the genesis and motive of the act of July $2,1890 .{ }^{226}$

That view of the political underpinning of antitrust law was not an outlier. Consider, for example, the following quote from a lecture delivered fortyone years later by Edward Levi. During World War II, Professor Levi served as a special assistant to the Attorney General of the United States and First Assistant in the Antitrust Division, and he gave the lecture after his return to the University of Chicago. His words are noteworthy not only because of his stature as an academic and as a statesman, but also because not too long after delivering this lecture he would become one of the cofounders of the law and economics movement. ${ }^{227}$ In discussing the history of antitrust and its traditions (including some of its internal confusions), Levi wrote the following:

And so it has been frequently urged that our heritage of an antipathy toward monopoly is really an heritage against the government grant which by conferring a property right in the exclusive possession of a field of business denied equality of opportunity. The protest against monopoly was a protest against the favorites of government. It is only by analogy, we are told, that the courts have been able to reason from the illegality of the monopoly obtained by the exclusive government grant, as in the Case of Monopolies, to "the illegality of any control of the market no matter how secured."

Our heritage against monopoly then is a heritage against exorbitant prices, unnaturally secured, and against the assertion of the exclusive right to do business based on a grant of government. But to these must be added also a belief in the rights of man. It is the right of every man to be free of restrictions except those recognized by law. It is the right of every man to engage in business and to seek his opportunity. ${ }^{228}$

Under this view, the enactment of the Sherman Act provided another step in the evolutionary process of the ages-long struggle "to secure the blessings of liberty." "229 It protects the right of every individual "to choose his own calling in life, and to follow the trade of his choice unhampered by any undue and unfair interference from others," 230 and secures this "blessing of liberty"

226 Motion Picture, 225 F. at 802.

227 For a biography of Edward Levi, see George W. Liebmann, The Common Law Tradition: A Collective Portrait Of Five Legal Scholars 11-78 (2006).

228 Edward H. Levi, The Antitrust Laws and Monopoly, 14 U. CHI. L. Rev. 153, 154 (1947) (internal citations omitted).

229 Motion Picture, 225 F. at 802.

$230 \mathrm{Id}$. 
not only against the "undue and unreasonable" exaction of government, but also against "any undue and unfair interference from others." ${ }^{231}$ Levi's reference to The Case of Monopolies reveals a conscious and unmistakable connection between Lord Coke's seventeenth century political thinking and Levi's twentieth century political thinking.

Therefore, even though the Motion Picture case was not an antitrust case but a patent law case, and was decided on the grounds of patent law as situated within a broader constitutional order, it would be a mistake to say that that case has nothing to do with antitrust law, because antitrust law and patent law each serve as the backdrop of the other. They work in tandem and share some common goals. Bowman, of course, recognized that point, but his error lies in his conviction that they share a single goal, described exclusively in economic terms: "to maximize wealth by producing what consumers want at the lowest cost." ${ }^{, 232}$ At some meta-level, this is undeniably true (or at least this is one of their goals, and hopefully also the result of their operation). However, neither of them contains any statutory prescription as to how to achieve that goal, let alone mandate the courts to decide on the basis of one or another view of how wealth might be maximized. But the two bodies of law also reflect a common understanding of the rule of law. IP law grants certain statutory monopolies and thus imposes legal limitations on the freedoms of others, while at the same time it defines the scope of these legal monopolies and ensures that those who hold them will not be able to impose greater limitations on the freedoms of others. Antitrust law ensures that private entities, through combinations and other exclusionary practices, do not impose limitations on the freedoms of others and purport in effect to exert regulatory powers without statutory basis. A careful reading of Motion Picture and other contemporaneous decisions reveals that at the heart of the Court's reasons were considerations about the rule of law and the distinction between private power and state (or public) power, rather than concerns about market power, and whether its exercise promotes or hinders efficiency.

Those cases, then, were not concerned with economic efficiency or maximizing aggregate wealth, but with protecting the rule of law and upholding the principle that every person has the right to be free of restrictions except those recognized by law. The objection to the extension of state-granted exclusive rights, by either private fiat or judicial construction, informed the Court's decisions about intellectual property in those formative years. In other words, it is adherence to a rule of law principle, rather than any strong endorsement of any economic analysis, that runs through the cases that irked

231 Id.

232 Bowman, supra note 2, at 1. 
Bowman and his fellow critics. This conclusion does not need to be arrived at through sophisticated deduction from other things that the Court had written; attentive reading of what it had said should suffice.

Motion Picture and its contemporaneous cases employed a familiar rule of law line of reasoning: by granting a patent or a copyright, the state delegates regulatory power to the owners of those statutory monopolies. This power allows them to exercise control over other persons and prevent them from doing things they otherwise would be legally permitted to do. The state, within constitutional bounds, may delegate such powers, but the rule of law requires that their exercise must be confined to the scope of the grant, and cannot be extended beyond that grant or applied arbitrarily. A patent or copyright, in that regard, is not different from the statutory powers given to the Tailors Company of Ipswich, the power of a parish to impose a Church Rate, ${ }^{233}$ the power of the Food Controller to license the distribution of milk, ${ }^{234}$ or the powers that the statute and the ordinance in Eubank purported to grant. In all of those cases the courts refused to allow those entrusted with such powers to extend them or apply them arbitrarily.

The statute and ordinance in Eubank were struck down because they established no standard by which the power could be exercised, leaving it susceptible to being used in an arbitrary, even capricious, way to advance sheer private interest. ${ }^{235}$ In Motion Picture, the Court did not strike down the patent, of course, but insisted that it could not be exercised beyond the scope of the statutory grant. Otherwise, it would bring about the same vice that concerned the Court in Eubank; it would become the

perfect instrument of favoritism and oppression ... if such restrictions were sustained, plainly the plaintiff might, for its own profit or that of its favorites ... ruin anyone unfortunate enough to be dependent upon its confessedly important improvement for the doing of business. ${ }^{236}$

The same rule of law considerations played a key role in other cases that the Court decided during that period. Those cases established the first sale doctrine, or the principle of exhaustion of IP rights, and circumscribed the limits of contributory liability for the infringement of patents and copyrights. I discuss those below.

233 Supra note 140.

234 Supra note 140.

235 Eubank v. Richmond, 226 U.S. 137 (1912).

236 Motion Picture Patents Co. v. Universal Film Co., 243 U.S. 502, 515 (1917). 


\section{Copyright and Patent Exhaustion Cases}

In Bobbs-Merrill, the Court answered the question whether "the sole right to vend secure[d] to the owner of the copyright the right, after a sale of the book to a purchaser, to restrict future sales of the book at retail" and to impose by notice "a limitation at which the book shall be sold at retail by future purchasers, with whom there is no privity of contract." ${ }^{237}$ The Court concluded that the answer was no, and that the statute could not be given such a construction.

Many contemporary discussions of the first sale doctrine approach the question through the lens of a cost-benefit analysis, where those who support a narrow first sale doctrine (or no such doctrine at all) extol the benefits that would arise if IP owners could impose various downstream restraints, and those who defend the doctrine emphasize the social harms that its restrictions may bring about and the social benefits resulting from its continued vitality. ${ }^{238}$ Cost-benefit considerations of that kind, however, are conspicuously absent from the Court's decision, and the Court emphasized that the issue was purely a question of statutory construction. ${ }^{239}$

The crux of the Court's reasoning lies in the following passage:

This conclusion is reached in view of the language of the statute, read in the light of its main purpose to secure the right of multiplying copies of the work, - a right which is the special creation of the statute. True,

237 Bobbs-Merrill Co. v. Straus, 210 U.S. 339, 350 (1908).

238 See, e.g., Katz, supra note 125 (discussing different economic arguments for and against exhaustion); Guy A. Rub, Rebalancing Copyright Exhaustion, 64 EMORY L.J. 741 (2015).

239 Bobbs-Merrill, 210 U.S. at 350-51. In a recent article, Professors John Duffy and Richard Hynes relied on this statement from Bobbs-Merrill and argued that the Court's exhaustion jurisprudence was created with the sole purpose of establishing a boundary between IP law and other laws, and to confine IP law within its own domain and prevent it from displacing other laws. Exhaustion, in their description, is devoid of any normative consideration other than this formal line drawing. They further argued that in deciding those cases the Court further expressed complete agnosticism to IP owners' ability to achieve the same ends using other legal arrangements based on contract or property law. John F. Duffy \& Richard M. Hynes, Statutory Domain and the Commercial Law of Intellectual Property, 102 VA. L. Rev. 1, 10 (2016). In reply, Professors Guy Rub, Aaron Perzanowski and I argued that Duffy and Hynes's account is overly restrictive, and showed how the Court's exhaustion jurisprudence was based on earlier common law principles and reflected policy considerations. Ariel Katz et al., The Interaction of Exhaustion and the General Law: A Reply to Duffy and Hynes, 102 VA. L. Rev. OnLine 8 (2016). 
the statute also secures, to make this right of multiplication effectual, the sole right to vend copies of the book, the production of the author's thought and conception. The owner of the copyright in this case did sell copies of the book in quantities and at a price satisfactory to it. It has exercised the right to vend. What the complainant contends for embraces not only the right to sell the copies, but to qualify the title of a future purchaser by the reservation of the right to have the remedies of the statute against an infringer because of the printed notice of its purpose so to do unless the purchaser sells at a price fixed in the notice. To add to the right of exclusive sale the authority to control all future retail sales, by a notice that such sales must be made at a fixed sum, would give a right not included in the terms of the statute, and, in our view, extend its operation, by construction, beyond its meaning, when interpreted with a view to ascertaining the legislative intent in its enactment. ${ }^{240}$

The fact that the Court did not engage in any cost-benefit analysis does not mean that such an analysis had not crossed the justices' minds. Indeed, the first part of the paragraph could be read as suggesting that it would be sufficient for accomplishing the goals of copyright - the law's benefits to recognize only a right to control the first sale of copies of books, and that interpreting the statute in a way that allows the copyright owner to exercise greater control downstream imposes gratuitous costs on the public. But if the decision depended solely on that view, it could be open to criticism that the question of which interpretation of the statute is optimal from a cost-benefit perspective is ultimately an empirical one, and the record before the Court could not support a ruling based on empirical considerations. The problem, however, is that had the Court held the opposite, namely that the purpose of copyright law justifies an expansive reading of scope of the plaintiff's copyright, it would be open to the same criticism.

Therefore, the key to the Court's reasoning lies in the last sentence. This appears to me like a classic rule of law reasoning: the statute grants an exclusive right to vend - no question about that - but how far does this exclusive right reach? This, the Court reasoned, is a question of statutory interpretation, but it must be admitted that, as a matter of plain language, the sole right to vend is unqualified. The Court, then, had to choose between an expansive construction of the sole right to vend, or a more restrictive one, and it chose the one that would not include the power to control all future retail sales, by a notice that such sales must be made at a fixed sum. The Court

240 Bobbs-Merrill, 210 U.S. at 350-51. 
declined to choose the more expansive construction because it recognized that doing so would allow the copyright owner unilaterally to decide what any lawful purchaser could do with a purchased copy in the future. Such a construction would permit the copyright owner "to qualify the title of a future purchaser," ${ }^{241}$ and then call upon the courts to impose such controls in an action for copyright infringement. This, in the Court's eyes, "would give a right not included in the terms of the statute, and, in our view, extend its operation, by construction, beyond its meaning, when interpreted with a view to ascertaining the legislative intent in its enactment."242

But again, when the case was decided the statute did not include any explicit language that restricts those powers (unlike the present $\mathrm{Act}^{243}$ ), so it was not self-evident that Congress had not granted such powers. Likewise, invoking "legislative intent" could quite plausibly point the other way: more power to the copyright owner might generate more income, and arguably "promote the progress of science," the presumptive legislative intent. In fact, this was the view held by courts in many common law jurisdictions at the time. For example, in 1908, the same year the U.S. Supreme Court decided BobbsMerrill, the High Court of Australia was divided on the question whether a patentee's exclusive right to "vend" the patented article conferred upon it the power to maintain the resale price of the patented articles. ${ }^{244}$

The majority opinion in the High Court of Australia, written by Chief Justice Griffith, was remarkably similar to that of the U.S. Supreme Court in Bobbs-Merrill. He began his analysis by noting that it had been accepted for nearly three hundred years after the passage of the Statute of Monopolies that once a patentee or his licensees had produced an article and disposed of it to some member of the public, any subsequent use of the article would not infringe the patentee's exclusive right of "working or making" the invention. ${ }^{245}$ The main precedents that he provided to support this proposition were the decisions of the U.S. Supreme Court in Bloomer v. Millinger, ${ }^{246}$ Chaffee v. Boston Belting Co., ${ }^{247}$ and Adams v. Burks. ${ }^{248}$ These precedents, however, could not resolve the matter immediately, because a legislative amendment

\section{$241 \mathrm{Id}$. at 951.}

242 Id.

24317 U.S.C. $\$ 109$ (2012).

244 Nat'l Phonograph Co. of Austl. v Menck (1908) 7 C.L.R. 481, rev'd in part, Nat'l Phonograph Co. of Austl. v. Menck (1911) 12 C.L.R. 15 (PC) (appeal taken from Austl.).

245 Id. at 509.

246 Bloomer v. Millinger, 68 U.S. 340 (1863).

247 Chaffee v. Boston Belting Co., 63 U.S. 217 (1859).

248 Adams v. Burks, 84 U.S. 453 (1873). 
(in Britain in 1883, and subsequently in Australia in 1906) introduced an exclusive right to "vend" the invention. Depending on its construction, this legislation could have resulted in a radical change in the law of personal property, and recognized a special class of chattels, which could not be alienated without the consent of an owner of a patent covering an invention embodied in them. ${ }^{249}$ Having regard to the statutory history, "and to the recognized rule that the legislature is not to be taken to have made a change in the fundamental principles of the common law without express and clear words announcing such an intention," Chief Justice Griffith rejected such construction and concluded that "the words 'vend the invention' mean to put the product of the invention in the possession of the public, and do not refer to any sale of the article after it has once, without violation of the monopoly, become part of the common stock." ${ }^{250}$

Justice Isaacs, dissenting, took a different position. Beginning with the same common law principles, including the premise that "no person [could] impose a condition repugnant to his grant, a doctrine applicable equally to real and personal property. ... [And] no person [could] of his own will create a new species of property, or impress upon property a character which the law does not recognize, or create a negative obligation to follow or attend ordinary rights of ownership," ${ }^{251}$ he continued to note that the Act of Parliament that gave patentees an exclusive right to "vend" created an exception to the general unfettered alienability of property. This Act of Parliament, enacted for the public welfare, rendered the general common law principles inapplicable to the case, with the result that an article that embodies an invention is, in effect, a new species of property. ${ }^{252}$ The grant of an exclusive statutory right to vend the patented article meant that any person who sells the article without a license from the patentee infringes the patent. Therefore, if the patentee could deny a license altogether, he also had the right to do the lesser thing, that is to say, to impose his own conditions, and it does not matter how unreasonable or how absurd the conditions are..$^{253}$

On appeal, the Privy Council rejected both propositions. ${ }^{254}$ Lord Shaw stated the general principle that in the absence of a valid contract to the contrary, an owner of an ordinary good may use and dispose of the good as

249 Menck (1908) 7 C.L.R. at 512.

$250 \mathrm{Id}$.

251 Id. at 536.

$252 \mathrm{Id}$.

253 Id. at 539.

254 Nat'l Phonograph Co. of Austl. v. Menck (1911) 12 C.L.R. 15 (PC) 21 (appeal taken from Austl.). 
he thinks fit. "It would be contrary to the public interest and to the security of trade, as well as to the familiar rights attaching to ordinary ownership, if any other principle applied." ${ }^{255}$ They recognized, however, the tension between this general principle and the statutory right of a patentee "to make, use, exercise, and vend the invention." ${ }^{256}$ They maintained, however, that "it [was] perfectly possible to adjust the incidence of ownership of ordinary goods with the incidence of ownership of patented goods in such a manner as to avoid any collision of principle." ${ }^{257}$ They reconciled the two principles by holding "that the general doctrine of absolute freedom of disposal of chattels of an ordinary kind is, in the case of patented goods, restricted when the patentee attaches conditions which the buyer becomes aware of at the time of sale. ${ }^{258}$ Notice of the restrictions will bind the buyer, and enforcing them is justified because "[ $\mathrm{t}]$ hese limitations are merely the respect paid and the effect given to those conditions of transfer of the patented article which the law, laid down by Statute, gave the original patentee a power to impose." 259 Moreover, Lord Shaw further held that binding the buyer to comply with restrictions communicated to him at the time of sale is also justified as a matter of principle, because inasmuch as the patentee can prevent others from using the invention altogether, he has the right to permit uses subject to any conditions he sees fit, no matter how unreasonable or how absurd the conditions are. As long as the buyer is free to take it or leave it, he will be bound by the condition if he has chosen to take it. ${ }^{260}$

The comparison between Menck and Bobbs-Merrill and its progeny is instructive for several reasons. First, all the judges applied the same methodology of examining first what were the common law rights of purchasers of ordinary goods before proceeding to determine whether the IP statutes conferred upon IP owners the power to modify those common law rights. All of them agreed on what the common law baseline was, but reached different conclusions on how the grant of an IP right affected it. Second, all the different judges explained that they were merely interpreting the statutes, and their different conclusions cannot be attributed to any disagreement on the lexical meaning of the word "vend" or on the grammar of the provisions where it appeared. ${ }^{261}$ Moreover,

255 Id. at 22 .

$256 \mathrm{Id}$.

$257 \mathrm{Id}$.

258 Id. at 24.

$259 \mathrm{Id}$.

$260 \mathrm{Id}$. at 26.

261 The Privy Council noted that "[s]ubstantially, nothing depends upon the particular wording of this section, ... it being admitted by the parties that their rights are 
in interpreting this word they operated within the same legal tradition and looked at the same body of case law, yet the judges of the various courts still reached very different conclusions about what those statutes meant.

It is also noteworthy that when the Court decided Bobbs-Merrill, a copyright case, the American case law on the ability of patentees to rely on their patents to impose post-sale restraints, while still unsettled, seemed to be moving in the direction of recognizing such powers. Both sides at the Australian High Court relied on those cases: the majority to emphasize that they were inconclusive, while the dissent regarded them as authorities to follow. In Bobbs-Merrill, however, the Court went to great lengths to distinguish the patent cases both on their facts, but also on the basis that it was dealing with rights under the copyright act and not with patents.

And indeed, when four years later, in Henry v. A.B. Dick Co. ${ }^{262}$ the question, this time with respect to patents, came before the U.S. Supreme Court, the majority distinguished Bobbs-Merrill, and emphasized that even though both statutes granted IP owners an exclusive right to "vend," Bobbs-Merrill was not controlling. The Court reviewed the earlier American cases as well as the English cases, including the Privy Council decision in Menck, and endorsed its holding. ${ }^{263}$ By 1912, then, the highest Anglo-American courts held that a patentee's exclusive right to vend allowed him to impose restraints on buyers of a patented article, and the holding in Bobbs-Merrill was an outlier.

But the Dick decision was short-lived, and within a year the U.S. Supreme Court began to reverse course, holding in Bauer v. O'Donnell ${ }^{264}$ that the right to "vend" had the same meaning in the copyright and the patent statutes, and holding, as in Bobbs-Merrill, that the right to restrict subsequent sales by notice was not among the exclusive rights that Congress granted to patentees. ${ }^{265}$ And four years later Justice White's dissent from Henry v. A.B. Dick Co. became the law of the land when, in Motion Picture, the Court formally overruled Dick. ${ }^{266}$ In less than a decade, the U.S. Supreme Court adopted a position that was markedly different from that of its British counterpart, as well as from its own earlier position.

What explains this dramatic reversal? In my view, the change can be best attributed to the renewed interest in the limits of private power in the

not varied by the differences, if any, between the language of the Australian and the British Patent Acts." Id. at 17.

262 Henry v. A.B. Dick Co., 224 U.S. 1 (1912).

263 Id. at 43-44.

264 Bauer \& Cie. v. O’Donnell, 229 U.S. 1 (1913).

265 Id. at 17.

266 Motion Picture Patents Co. v. Universal Film Co., 243 U.S. 502, 518 (1917). 
United States, reflected in, and precipitated by, the passage of the antitrust laws. While the British judiciary was still rooted in the laissez faire era, the American courts had already moved away from it. Laissez faire attitudes manifested themselves twice in Menck. First, it was common ground that restrictions pursuant to valid contract between the patentee and the purchaser would be enforceable. This view was shared by all the judges of the High Court of Australia as well as by the Privy Council, but as I discuss in the next Section, this view had already started to erode in the United States. Second, key to the holding of the Privy Council was the view that a buyer who, at the time of sale, has become aware of conditions set by the seller will be bound by the conditions no matter how unreasonable or absurd the conditions are. ${ }^{267}$

The majority in Henry v. A.B. Dick Co. adopted the same rule, but Chief Justice White wrote a vigorous dissent, joined by Justices Hughes and Lamar. The majority held that the plaintiff's patent embodied in a mimeograph machine allowed the patentee to license the use of the machine on the condition that it be used only with stencil paper, ink and other supplies sold by the plaintiff, that the user who breached the conditions could be liable for breach of contract as well as for infringement of the patent, and further that the defendant, who sold ink to the user having notice of the restrictive conditions, was liable for contributory infringement of the patent. The majority also held that the Court's ruling in Dr. Miles Medical Co. v. John D. Park \& Sons Co. ${ }^{268}$ decided a year earlier, which invalidated agreements to maintain the retail prices of non-patented articles ${ }^{269}$ was inapplicable to agreements with respect to patented articles. ${ }^{270}$

Chief Justice White provided a long list of objections, based on precedent, principle, and public policy considerations. But the strong words he used to describe the consequences of the majority decision show his fundamental disagreement with the approach of the majority. After describing several examples demonstrating the implications of allowing patentees to control the sale and use of non-patented articles, he warned that the holding would tend "to subject the whole of society to a widespread and irksome monopolistic control." ${ }^{271} \mathrm{He}$ was concerned that the various techniques with which patentees purported to extend their control would "tend to increase monopoly and

267 Nat'l Phonograph Co. of Austl. v. Menck (1911) 12 C.L.R. 15 (PC) 26 (appeal taken from Austl.).

268 Dr. Miles Medical Co. v. John D. Park \& Sons Co., 220 U.S. 373, 404 (1911).

$269 \mathrm{Id}$.

270 Henry v. A.B. Dick Co., 224 U.S. 1 (1912).

271 Id. at 55-56. 
to burden the public to the exercise of their common rights." ${ }^{272}$ The term "common rights" is synonymous with "common law rights," 273 and Justice White's concerns were not economic but constitutional. "My mind cannot shake off the dread of the vast extension of such practices which must come from the decision of the court now rendered," he wrote. ${ }^{274}$ Who could "put a limit upon the extent of monopoly and wrongful restriction which will arise?" he asked. ${ }^{275} \mathrm{He}$ was not troubled by concerns about productive or allocative inefficiency, but with a holding that would allow some members of the community to subject others to their arbitrary demands.

Unlike the Privy Council, which saw no fault in enforcing arbitrary conditions as long as they were communicated to the buyer, Justice White dreaded such an outcome. The problem with the ruling of the majority was that it allowed the limited statutory exclusive right to vend an article embodying the invention to transform into boundless power to control the activities of others, and determine the scope of their property rights and other legal entitlements. This result would allow IP owners to enlist the coercive power of the state and impose their wishes on others. Such powers are the hallmark of a "system of government based on the exercise by persons in authority of wide, arbitrary, or discretionary powers of constraint" - the antithesis of the rule of law. ${ }^{276}$

Conceptually, the problem, as Justice White identified it, was the same problem that the Court confronted in Eubank several months later. In Eubank an enactment conferred upon some members of the community wide and unbounded discretionary powers to control and redefine the rights of others. Without providing any standard by which the power was to be exercised, it was prone to be exercised solely for private interest or even capriciously. ${ }^{277}$

272 Id. at 70.

273 See, e.g., Strother v. Lucas, 37 U.S. 410, 437 (1838) ("[The right] exists by a common right, which means a right by common law ....”); see also Sis v. Boarman, 11 App. D.C. 116, 128 (D.C. Cir. 1897) ("This record [of deeds and conveyances of land] system, so universal with us, although practically unknown to the common law, is not in derogation of the common law or of common right, but a most valuable adjunct to it ....").

274 Henry, 224 U.S. at 70.

275 Id. at 71.

276 Dicey, supra note 15, at 184. Dicey's definition of the rule of law included two additional components: that no man is above the law and that officials are bound by the same laws as ordinary subjects, $i d$. at 189 , and the recognition and protection of individual rights and other constitutional principles through the operation of the common law courts rather than formal constitutional documents, id. at 191.

277 Eubank v. Richmond, 226 U.S. 137, 143-44 (1912). 
The problem with the holding in Dick was that the Court's ruling resulted in a situation where a patentee's limited statutory powers of constraint over his invention could be extended to constrain the sale and use of articles forming no part of the invention, and impose any condition, no matter how arbitrary or even absurd it might be.

Indeed, that the Court sought to prevent the exercise of arbitrary power is evident from the judgement in Motion Picture, where the Court overturned Dick. The Court described the attempts by patentees to impose various restraints extending beyond scope of the patent as a "perfect instrument of favoritism and oppression." Sustaining these restrictions would allow the patentee, "for its own profit or that of its favorites [to] ruin anyone unfortunate enough to be dependent upon its confessedly important improvements for the doing of business." ${ }^{278}$

In Straus v. Victor Talking Machine Company, ${ }^{279}$ argued and decided concurrently, the Court expressed similar concerns. The Court held that the plaintiff's attempt to maintain the retail price of its gramophone machines by affixing a "License Notice" could not be maintained because the license notice was a naked attempt "to sell property for a full price, and yet to place restraints upon its further alienation, such as have been hateful to the law from Lord Coke's day to ours, because obnoxious to the public interest." ${ }^{280}$

In sum, while the Privy Council's laissez faire attitude drove it to uphold any restriction of which the buyer was made aware at the time of sale, no matter how arbitrary or absurd the restriction might be, the U.S. Supreme Court had become highly suspicious of endorsing a system that permitted patentees to exercise wide, arbitrary, or discretionary powers of constraint. Justice White's concerns echo the Diceyan conception of the rule of law. If the rule of law mandates that "no man is punishable or can be lawfully made to suffer in body or goods except for a distinct breach of law established in the ordinary legal manner before the ordinary Courts of the land," ${ }^{281}$ it requires courts to enforce only the restrictions that the legislature determined that a patentee could impose and only those that fall within the scope of the patented invention. Allowing patentees to arrogate powers to control activities beyond the scope of their patented invention through the simple expedient of providing notice violates the rule of law in two important respects: first, it elevates the patentee to a level of super-legislator, because it gives the patentee powers to control the exercise of other people's common law rights, over and above

278 Motion Picture Patents Co. v. Universal Film Co., 243 U.S. 502, 515 (1917).

279 Straus v. Victor Talking Machine Co., 243 U.S. 490 (374).

$280 \mathrm{Id}$. at $500-01$.

281 DiCEY, supra note 15, at 183-84. 
the restraints imposed by the legislature, and requires the courts to enforce those privately-imposed constraints. It results in a situation where a person could be legally sanctioned not for a distinct breach of law established in the ordinary legal manner, but for breaching the will of the patentee established by notice. Since the holding in Dick enabled the patentee to sue the supplier of the tied ink on the theory that he was aware of the restriction in the license agreement, it extended "the virtual legislative authority of the owner of a patented machine ... to every human being in society without reference to their privity to any contract existing between the patentee and the one to whom he has sold the patented machine." 282

Second, even if the legislation could be construed as delegating to the patentee such powers to control activities that extend beyond the scope of the patented invention, this would run afoul of the rule of law because it would in effect create a "system of government based on the exercise by persons in authority of wide, arbitrary, or discretionary powers of constraint" - the antithesis of the rule of law. ${ }^{283}$

\section{Contracting Around Exhaustion Rules and Other Limitations on IP Owners' Powers}

In addition to rejecting the prospect of creating enforceable restraints by notice, the U.S. Supreme Court diverged from the British courts in its attitude towards contractual restraints. Recall that while the judges of the High Court of Australia and the Privy Council in Menck disagreed on the scope of the powers given to a patentee, they were unanimous in the view that contractual restraints included in an otherwise valid contract would be valid. ${ }^{284}$ This view, of course, was consistent with the hollowing of the doctrine of restraints of trade during the laissez faire era. ${ }^{285}$ The passage of the antitrust laws in the United States, however, triggered renewed interest in the doctrine, which also influenced the Court's attitude towards contractual restraints and contractual workarounds of the rules of exhaustion.

In Bobbs-Merrill, the Court emphasized that there was "no claim in this case of contract limitation, nor license agreement controlling the subsequent sales of the book," and that the question before the Court was "purely a question of statutory construction." ${ }^{286}$ According to some, this dictum shows

282 Henry v. A.B. Dick Co., 224 U.S. 1, 54 (1912) (White, C.J., dissenting).

283 Id.

284 See supra note 267 and accompanying text.

285 See supra notes 114-119 and accompanying text.

286 Bobbs-Merrill Co. v. Straus, 210 U.S. 339, 350 (1908). 
that the Court was agnostic about IP owners' ability to use contracts to exert downstream control. ${ }^{287}$ But reading the Court's choice not to decide an issue that was not properly before it is a very poor signal of what the Court would have decided had the issue come before it. ${ }^{288}$ And it did not take long before the issue came before the Court.

A year before the Court decided Bobbs-Merrill, the Sixth Circuit held that agreements to fix the retail price of proprietary medicines, not subject to a patent, were void under the common law as unreasonable restraints on trade, and under the Sherman Act inasmuch as they concerned interstate commerce. ${ }^{289}$ Judge Lutton's decision, however, emphasized that the medicine at issue was not patented. That was crucial, because in his view it was "well settled" that patentees and copyright owners could control the resale price of patented articles or copyrighted works, and that contracts entered into for that purpose "if otherwise valid, are not within the terms of the [Sherman Act] or the rules of the common law against monopolies and restraints of trade." 290

When a similar case involving the same defendant and similar price maintenance came before the Supreme Court in 1911, the Court adopted the same line of reasoning and agreed that the contract was unenforceable because the restrictions were invalid both at common law and under the Sherman Act. ${ }^{291}$ But the Court was less conclusive with respect to patentees' and copyright owners' powers to enter into such contracts. It noted that "whatever rights the patentee may enjoy are derived from statutory grant under the authority conferred by the Constitution" and therefore could not be relied on in a case involving a formula not protected by a patent. ${ }^{292}$

The following year, Justice Lutton, now of the Supreme Court, wrote the opinion of the majority in A.B. Dick, which, consistent with his earlier ruling as a judge of the Sixth Circuit, held that patentees could indeed impose downstream restraints, and he viewed $D r$. Miles as standing for the proposition that patentees were exempt from whatever limitations on contracts in restraint of trade existing under the common law or the Sherman Act. ${ }^{293}$ Chief Justice White disagreed that Dr. Miles stood for that proposition, ${ }^{294}$ but went on to say that even if he accepted arguendo that a patent entailed the extraordinary

287 See, e.g., Duffy \& Hynes, supra note 239.

288 Katz et al., supra note 239, at 15.

289 John D. Park \& Sons Co. v. Hartman, 153 F. 24, 33 (6th Cir. 1907).

$290 \mathrm{Id}$. at 26.

291 Dr. Miles Medical Co. v. John D. Park \& Sons Co., 220 U.S. 373, 409 (1911).

292 Id. at 401-02.

293 Henry v. A.B. Dick Co., 224 U.S. 1, 39 (1912).

$294 \mathrm{Id}$. at 54. 
power to enter into such contracts, he would still maintain that the exercise of such power, like every other power, should be subject to the law of the land:

To conclude otherwise would be but to say that there was a vast zone of contract lying between rights under a patent and the law of the land, where lawlessness prevailed and wherein contracts could be made [irrespective of their reasonableness] so as to dominate and limit rights of every one in society, the law of the land to the contrary notwithstanding. ${ }^{295}$

As noted, the Court overruled Dick in Motion Picture, and the following year, in Boston Store of Chicago v. American Graphophone Co., Chief Justice White, now writing for the majority, reviewed the Court's recent case law, from Bobbs-Merrill to Motion Picture, and concluded that the agreement to maintain the resale prices was void under the general law, and that the grant of a patent does not include the power to make contracts in derogation of the general law. ${ }^{296}$

It would appear from this discussion that by 1918 the Court foreclosed any possibility of entering into valid post-sale agreements. If that were the case, then it would have been too harsh — after all the common law doctrine of restraints of trade, which the Court relied on in Dr. Miles, did not prohibit all types of restraints, but only those deemed unreasonable. Nevertheless, in the later case of Leegin Creative Leather Products v. PSKS, Inc., ${ }^{297}$ the Court interpreted Dr. Miles as establishing a per se rule against a vertical agreement between a manufacturer and its distributor to set minimum resale prices, ${ }^{298}$ a rule that the Court finally overturned in 2007, when it held that such agreements should be judged by the rule of reason, and declared that Dr. Miles ought to be overruled. ${ }^{299}$

Dr. Miles itself did not really establish any such rule. Indeed, the distinction between practices judged under rule of reason and those that are per se illegal

$295 I d$. at 69-70. In the brackets I used the phrase "irrespective of their reasonableness" instead of the original words "contracts could be made whose effect and operation would not be confined to the area described, but would be operative and effective beyond that area." I believe that in invoking the geographical unboundedness of the contractual limitations, Justice White alluded to one of the factors of unreasonableness under the restraint of trade doctrine.

296 Bos. Store of Chi. v. Am. Graphophone Co., 246 U.S. 8, 25 (1918).

297 Leegin Creative Leather Products v. PSKS, Inc., 551 U.S. 877 (2007).

298 Id. at 887.

299 Id. at 881. 
developed much later, ${ }^{300}$ and Dr. Miles held that the agreements were invalid because they were unreasonable, not that they were illegal per se. Moreover, $D r$. Miles was not an antitrust case, and therefore did not and could not establish a standard for liability for violations of section 1 of the Sherman Act. Dr. Miles involved an action against the defendant for malicious interference with the contracts between the plaintiff and other wholesalers and retailers. The contracts required the wholesalers to sell the plaintiff's products only to designated retailers, and required the retailers not to sell the product below a certain price. The defendant refused to sign such an agreement but obtained the plaintiff's products from some of the wholesalers who sold them at discount. The plaintiff alleged that the defendant unlawfully and fraudulently procured the proprietary medicines from the plaintiff's agents in violation of their contracts. ${ }^{301}$ Holding that the contracts were invalid under the common law as well as under the Sherman Act, the Court dismissed the plaintiff's complaint. ${ }^{302}$ Therefore, the principle that contracts that restrain trade unreasonably are invalid did not originate in $\mathrm{Dr}$. Miles and cannot be affected by its subsequent overruling. Likewise, the principle that the grant of a patent or a copyright does not include the power to enter into agreements that would otherwise be held invalid remains as valid after Leegin as it was before. The question, therefore, is not whether agreements between IP owners and others would ever or never be valid, but which ones would be and which ones would not.

Elsewhere, I have argued that while the law should not categorically invalidate any attempt to contract around exhaustion, exhaustion (or other limitation on the exclusive rights of IP owners) should be treated as a sticky default rule. The law should not categorically invalidate any attempt to contract around them, but it should also require those who seek to enforce the restraints to justify their efficiency and reasonableness before a court will uphold them. I argued that when the restraints purport to bind third parties or have longterm effects, the dose of suspicion should increase. ${ }^{303} \mathrm{I}$ have defended this argument mainly on economic grounds, but it can also be defended on rule

300 See, e.g., N. Pac. Ry. Co. v. United States, 356 U.S. 1, 5 (1958) (explaining that the principle of per se unreasonableness pertains to "certain agreements or practices which because of their pernicious effect on competition and lack of any redeeming virtue are conclusively presumed to be unreasonable and therefore illegal without elaborate inquiry as to the precise harm they have caused or the business excuse for their use").

301 Dr. Miles Medical Co. v. John D. Park \& Sons Co., 220 U.S. 373, 397-98 (1911).

$302 \mathrm{Id}$. at 409.

303 Ariel Katz, The Economic Rationale of Exhaustion: Distribution and Post-Sale Restraints, in Research Handbook on IP Exhaustion and Parallel Imports 23 (Irene Calboli \& Edward Lee eds., 2016); Katz, supra note 125; Ariel Katz, 
of law grounds, and it would be consistent with the historical common law treatment of agreements in restraint of trade.

As noted above, the enactment of the Sherman Act triggered renewed interest in the doctrine of restraint of trade in the United States and Judge Taft's ruling in Addyston Steel ${ }^{304}$ from 1898 was one of the foundational cases for the doctrine's revival. After describing the history of the doctrine, Judge Taft emphasized that a partial restraint of trade would be reasonable not only if it protects the interests of the parties, but also if it does not interfere with the interests of the public. ${ }^{305}$ A reasonable restraint would be one that is merely ancillary to an otherwise legitimate contract and where it is

inserted only to protect one of the parties from the injury which, in the execution of the contract or enjoyment of its fruits, he may suffer from the unrestrained competition of the other. The main purpose of the contract suggests the measure of protection needed, and furnishes a sufficiently uniform standard by which the validity of such restraints may be judicially determined. In such a case, if the restraint exceeds the necessity presented by the main purpose of the contract, it is void . . . ${ }^{306}$

Judge Taft criticized more recent decisions where British, Canadian, and American courts had upheld contracts where the restraint was not ancillary and necessary to the attainment of an otherwise lawful purpose, but the main object of the contract. In misunderstanding the rationale behind the relaxation of the rules regarding reasonableness, he argued, those courts had "set sail on a sea of doubt" and "assumed the power to say, in respect to contracts which have no other purpose ... than the mutual restraint of the parties, how much restraint of competition is in the public interest, and how much is not."307 Not only was the assumption of power to regulate prices by the contracting parties inconsistent with the rule of law, but adopting a "shifting, vague, and indeterminate [legal] standard" for determining how much private regulation would be in the public interest created a "manifest danger in the administration of justice and would seem to be a strong reason for rejecting it." 308

Decades later, Taft's judgment and the notion of "ancillary restraints" became the cornerstone for antitrust law's relaxed stance towards vertical

Copyright and Competition Policy, in Handbook of the Digital Creative ECONOMY 209, 217 (Ruth Towse \& Christian Handke eds., 2013).

304 United States v. Addyston Pipe \& Steel Co., 85 F. 271 (6th Cir 1898).

305 Id. at 282 (citing Horner v. Graves (1831) 131 Eng. Rep. 284 (C.P.) 287).

$306 \mathrm{Id}$.

307 Id. at $283-84$.

308 Id. at 284. 
restraints, driven by the Chicago School lawyers and economists. ${ }^{309}$ However, Taft's framework fits perfectly well with the Court's early twentieth century jurisprudence that they attacked. In fact, the rule of law perspective shows that the Court invalidated the various schemes to impose post-sale restraints either because it was not convinced that the restraints were ancillary to an otherwise legitimate business enterprise, or, and more importantly, because they exceeded what was necessary to protect the interests of the one or both contracting parties and purported to interfere with the interests of the public.

In the cases involving IP (Bobbs-Merrill, Dick, Bauer, Motion Picture, Victor, and Boston Graphophone), the plaintiffs did not seek to enforce restraints against specific contractual parties on the basis that they were ancillary to and necessary for the execution of the contract or the enjoyment of its fruits. Instead, they asserted that their IP rights exempted them from the requirements of reasonableness. They maintained that their IP rights entitled them to impose any restraint, including those pertaining to activities or articles over which they had no exclusive rights, and enforce it under the guise of a patent or copyright infringement, not only against those with whom they had privity of contract, but also against anyone who does not comply with the restriction or contributes to its breach. Not only did such ambitious claims not comport with the requirements of ancillarity and proportionality in Judge Taft's formulation, but they also could not be reconciled with the rule of law, as they implied a vast zone of private ordering "where lawlessness prevailed" and IP owners could "dominate and limit rights of every one in society, the law of the land to the contrary notwithstanding." 310

This perspective also helps explaining why in United States v. General Electric, ${ }^{311}$ Taft, now as the Supreme Court Chief Justice, distinguished the line of cases from Bobbs-Merrill, via Dr. Miles to American Graphophone,

309 Robert H. Bork, Ancillary Restraints and the Sherman Act, 15 A.B.A. SEC. Antitrust L. 211 (1959).

310 Henry v. A.B. Dick Co., 224 U.S. 1, 69-70 (1912) (White, C.J., dissenting). The contracts in Dr. Miles suffered from a similar problem: They were more than contracts, but

a system of interlocking restrictions by which the complainant seeks to control not merely the prices at which its agents may sell its products, but the prices for all sales by all dealers at wholesale or retail, whether purchasers or subpurchasers, and thus to fix the amount which the consumer shall pay, eliminating all competition.

Dr. Miles Medical Co. v. John D. Park \& Sons Co., 220 U.S. 373, 399 (1911). Moreover, under the plaintiff's theory of the case it was entitled to recourse against the defendant with whom it had no contractual relations. Id.

311 United States v. Gen. Elec. Co., 272 U.S. 476 (1926). 
and found their holdings inapplicable to the case at hand. He held that unlike in Dr. Miles, the contracts between General Electric and its sales agents created genuine agency, and in dictating to its agents the prices they should charge the company did not violate the antitrust laws. ${ }^{312} \mathrm{He}$ also held that General Electric, as a patentee, could determine the sale prices that its licensee should charge, especially when it was also manufacturing and selling the same product. Because the sale price of the licensee affects the sale price and profit of the patentee, the restriction was reasonably necessary to secure pecuniary reward for the patentee's monopoly. ${ }^{313}$ Moreover, the restriction on the price in that instance had a more direct relation and was more germane to the rights of the patentee than the restrictions in Dick or Motion Picture, which concerned unpatented material with which the patented article may be used. Additionally, they only applied to the first sales by the licensee, and did not purport to impose a condition running with the article in the hands of subsequent purchasers, as was the case in Bobbs-Merrill, Bauer, Victor, or American Graphophone. ${ }^{314}$

The rule of law perspective also solves a puzzle - an apparent discrepancy between how IP law treats post-sale restraints and how antitrust law treats them. Under modern antitrust law, vertical restraints are subject to rule of reason analysis, meaning that the burden is on the plaintiff to show that an agreement in restraint of trade produces the requisite anticompetitive effect. This has led some commentators to argue that IP owners too should be able to impose post-sale restraints and rely on their IP rights to enforce them unless it can be shown that those restraints result in a concrete harm to competition or to innovation. ${ }^{315}$

The U.S. Supreme Court, however, has so far been stubborn. It declined to change course and continued to view the first sale doctrine as a categorical IP rule. From an economic point of view, this discrepancy might seem puzzling, but from a rule of law perspective it seems obvious. Under the common law, contracts that constituted unreasonable restraint of trade were not unlawful in the sense of being criminal, or in the sense of giving rise to a civil action for damages by those injured by them. Rather, they were simply void, and unenforceable. The antitrust laws, however (in addition to reinvigorating what could be considered an agreement in restraint of trade), provided new remedies

$312 I d$. at 488.

313 Id. at 490.

314 Id. at 493-94.

315 E.g., Christina Bohannan \& Herbert Hovenkamp, Creation Without Restraint: Promoting Liberty and Rivalry in InNOvation 393 (2011). 
and imposed new liabilities. ${ }^{316}$ In Hohfeldian terms, a holding that a contract in restraint of trade is invalid concerns an issue of legal disability, whereas a holding that in addition to being invalid, such a contract has violated the Sherman Act changes the mere disability into liability. The difference between mere disability and liability has implications for the rule of law, because generally the rule of law mandates that a person cannot be held liable unless that person's liability has been established as a matter of law, with evidence meeting the appropriate standard of proof.

Likewise, an IP owner who attempts to impose a downstream restraint, even an unreasonable one, is not, as a matter of IP law, guilty of any offence or liable to pay damages, but is merely disabled from harnessing the court to impose its wishes on others. When a court declares that an IP owner's right has been exhausted (or otherwise does not extend beyond a certain scope), and therefore declines to hold the defendant liable for infringing a right that does not exist, the court does not deprive anyone of any preexisting right. Rather, the court merely preserves the common law baseline and maintains the rule of law "that no pecuniary burden can be imposed upon the subjects of this country, by whatever name it may be called, whether tax, due, rate or toll, except upon clear and distinct legal authority, established by those who seek to impose the burthen." ${ }^{317}$ However, if, in addition to a finding that the IP owner is disabled from imposing its wishes on others, his attempt to impose the restraint could trigger antitrust liability, requiring the plaintiff to show that the challenged restraints indeed produce the requisite anticompetitive effect comports with the same rule of law principle. ${ }^{318}$ In short, since exhaustion only implies legal disability, whereas antitrust law involves liability, the fact that the former is categorical while the latter requires proof presents no puzzle at all.

316 United States v. Addyston Pipe \& Steel Co., 85 F. 279.

317 Gosling v. Veley (1850) 12 QB 328 (Ct. Ex. Ch.) 407 (Wilde, C.J., dissenting) (UK).

318 It does not follow that per se violations of the antitrust laws are inconsistent with the rule of law. The legislature may decide to prohibit certain acts whether or not they result in the harm that the act seeks to avoid, and then the rule of law would require that the plaintiff prove that the defendant had committed the prohibited act. Likewise, the courts may over time and through experience recognize certain practices that are presumed to be unreasonable restraints on competition. Broad. Music Inc. v. CBS, 441 U.S. 1, 10 (1979). But when the harmful effect constitutes part of the definition of the offence the rule of law would require the plaintiff to prove those harmful effects. 


\section{E. Contributory Liability}

Contributory liability for the infringement of patents and copyrights allows the IP owner to seek relief not only against those who directly infringe their exclusive rights but also against a broader range of defendants the actions of which make the direct infringers' actions possible, or easier. Courts have justified their willingness to expand the scope of those who can be held liable by the need to enable IP owners to enforce their rights when they are infringed by a large number of persons whom it would be impractical to sue together. ${ }^{319}$ Like debates on the practice of tying and other post-sale restraints, contemporary discussions on contributory liability in copyright and patent law seek to find an optimal, or "efficient," scope of contributory liability, one that acknowledges the impracticability or futility of suing a multitude of individual infringers ${ }^{320}$ but does not deter innocent and non-infringing uses as well.

Often, the question is framed as one aspect of IP law's perennial dilemma: the tension between the competing values of supporting creativity through IP protection and promoting technological innovation by limiting infringement liability. ${ }^{321}$ Under this approach, determining the right scope of contributory liability requires cost-benefit analysis. If there is a third party who either contributes to the infringement or can end or prevent the infringement, and holding that person liable can end the infringement in a more cost-effective way compared to suing the individual infringers, then, the argument goes, that person should be held liable. This would encourage the contributor to take measures to end or prevent the infringement. Holding the contributor liable would bring about the benefit of reduced infringement at the lowest social cost. This is a straightforward application of the concept of the least-cost avoider from the law and economics of tort law: the party who can avoid the harm at the lower cost should have a duty to take measures to avoid such harm. ${ }^{322}$

So far so good, except that in some cases, the contributor does more than merely facilitate the infringement. For example, the person might provide tools

319 Charles W. Adams, A Brief History of Indirect Liability for Patent Infringement, 22 Santa Clara Computer \& High Tech. L.J. 369 (2006).

320 In re Aimster Copyright Litig., 334 F.3d 643, 645 (7th Cir. 2003) (citing Randal C. Picker, Copyright as Entry Policy: The Case of Digital Distribution, 47 Antitrust Bull. 423, 442 (2002)).

321 See, e.g., Metro-Goldwyn-Mayer Studios Inc. v. Grokster, Ltd., 545 U.S. 913, 928 (2005) ("The tension between the two values [supporting creative pursuits through copyright protection and promoting innovation in new communication technologies] is the subject of this case.").

322 Guido Calabresi, The Costs of Accidents: A Legal and Economic Analysis $135-40$ (1970) 
that can be employed for both infringing and non-infringing uses. Holding that person liable may prevent or reduce the incidence of the infringing uses (good/benefit), but may also prevent or impair current or future non-infringing uses and other desirable activities (bad/cost). From this point of view, an optimal contributory liability rule would somehow maximize the good while minimizing the incidence of the bad. Formulating the rule on this basis sounds sensible in theory, although applying it may present intractable difficulties. It requires the decision-maker not only to identify and have a good measure of the incidence of the bad and the good (i.e., the relative scope of the good uses of the third-party device and the bad uses), but also to quantify the social harms and benefits of such uses.

The courts, however, in formulating the rules for contributory liability have chosen a different path, one that might seem somewhat peculiar to an observer applying that type of cost-benefit analysis, but which is more consistent with the rule of law. The following examples demonstrate this point.

\section{Early Patent Cases}

Wallace v. Holmes ${ }^{323}$ is considered the first judicial recognition of contributory liability in U.S. patent law. ${ }^{324}$ The case involved a patent for an improved oil lamp, consisting of a combination of a particular type of burner and a glass chimney. The defendants manufactured and sold burners that were substantially the same as the burner in the patented invention, but they never manufactured or sold any glass chimney. While the court recognized that in general a combination patent could not be infringed unless the defendant makes or uses all of its components, it held the defendant liable, because the component that the defendants manufactured and sold had no use except by those who infringe the patent. This indicated that the defendants must have intended to cause infringement of the patent.

In Morgan Envelope v. Albany, ${ }^{325}$ however, the Supreme Court distinguished Wallace and declined to hold the defendant contributorily liable. The patent involved the combination of two components: a fixture for holding rolls of toilet paper and a roll of toilet paper. While the combination was patented, toilet paper rolls were not. The plaintiff alleged that the defendant infringed the patent by selling toilet paper to be used with the plaintiff's fixture, by people who purchased the plaintiff's fixture. "The real question in this case," the Court said, was whether "the sale of one element of such combination, with

323 Wallace v. Holmes, 29 F. 74 (C.C.D. Conn. 1871).

324 Adams, supra note 319, at 371.

325 Morgan Envelope Co. v. Albany Perforated Wrapping Paper Co., 152 U.S. 425 (1894). 
the intent that it shall be used with the other element, is an infringement." 326 The Court held it was not, because toilet paper had to be replaced periodically and the patentee did not have the exclusive right to sell toilet paper to those who purchased the patented fixtures. Holding otherwise would give to the patentee of the combination the benefit of a patent upon the non-patented product, by requiring such a product to be bought of him. ${ }^{327}$

Several years later, in Leeds \& Catlin v. Victor Talking Machine Co., ${ }^{328}$ the Court reached a different conclusion. It held that a seller of an unpatented disc was contributorily liable for infringing the patent that covered a method for reproducing sounds from a record and stylus and a sound-reproducing apparatus consisting of a record and a stylus. Morgan Envelope was distinguished because the disc wasn't perishable and was an essential component of the operation of the invention, which depended on the joint action of the disc and the stylus. ${ }^{329}$ Note that the case was decided after Bobbs-Merrill but before Dick. It would be little surprise then that, like Dick, the decision was later overturned. The Court overturned the ruling in Mercoid v. Mid-Continent, ${ }^{330}$ and provided reasons that tracked the holding in Motion Picture, which by now will sound familiar: the grant of a patent is the grant of a special privilege that allows the patentee to be free from competition in the practice of the invention. But the scope of this exclusive right is narrowly and strictly confined to the precise terms of the grant, and it does not include the power to use it in such a way as to acquire a monopoly which is not plainly within the terms of the grant. If a patent covers a combination but not an individual component, the patentee lacks the power to tie the component to the sale of the patented machine, and therefore the patentee's attempt to use the patent to protect an unpatented part from competition provides a defense against a charge of contributory infringement. ${ }^{331}$

\section{Copyright Cases: Sony v. Universal}

In Sony v. Universal, ${ }^{332}$ two Hollywood studios sued Sony for contributorily infringing their copyrights, caused by consumer copying of TV programs using a VCR. Sony, of course, did not reproduce the works, but the consumers who used the VCR that it manufactured and sold did. Recognizing that the

$326 \mathrm{Id}$. at $432-33$.

327 Id. at 433.

328 Leeds \& Catlin Co. v. Victor Talking Machine Co., 213 U.S. 301 (1909).

329 Id.

330 Mercoid Corp. v. Mid-Continent Investment Co., 320 U.S. 661 (1943).

331 Id. at 668.

332 Sony Corp. of Am. v. Universal City Studios, Inc., 464 U.S. 417 (1984). 
"Copyright Act does not expressly render anyone liable for infringement committed by another," ${ }^{333}$ the majority of the Court looked for guidance to the rules of patent law regarding contributory liability, and adopted patent law's "staple article of commerce" doctrine. The Court explained:

The staple article of commerce doctrine must strike a balance between a copyright holder's legitimate demand for effective - not merely symbolic - protection of the statutory monopoly, and the rights of others freely to engage in substantially unrelated areas of commerce. Accordingly, the sale of copying equipment, like the sale of other articles of commerce, does not constitute contributory infringement if the product is widely used for legitimate, unobjectionable purposes. Indeed, it need merely be capable of substantial noninfringing uses. ${ }^{334}$

Applying this test, the Court concluded that Sony was not a contributory infringer, because the VCR had sufficient legitimate noninfringing uses: some copyright owners authorized viewers to record their programs, and even if they didn't, unauthorized time-shifting was held to be legitimate fair use.

From a purely economic cost-benefit perspective, the rule might seem unsatisfactory. Randal Picker uses the following hypothetical. Consider a third party who sells a device that generates $\$ 100$ worth of social benefit and $\$ 1000$ worth of social harm. "On balance," he argues, "this is clearly a terrible product, and if we forced the manufacturer to internalize the harm, it would never be produced. If instead we merely ask whether there are some beneficial uses, this product, and almost all others, will pass with flying colors." ${ }^{335}$ The Sony rule blesses the device even if its social costs exceed the benefits. ${ }^{336}$ Moreover, suppose that the manufacturer could spend $\$ 5$ to design the device to eliminate the social harm while still creating $\$ 100$ in social benefits. Should it spend the money to redesign? Picker asks. From an economic perspective, the answer is straightforward: of course. But alas, the holding of the majority in Sony removes any reason to redesign to minimize copyright infringement, whereas the possibility of such redesign was considered by the dissent. ${ }^{337}$

Yet, the majority did not brush such issues aside because it thought they were incorrect or unimportant. Rather, the majority opinion shows that as valid as those considerations might be, the Constitution and the rule of law minimize their relevance. The gist of the majority opinion appears in its

333 Id. at 434 .

$334 \mathrm{Id}$. at 442 .

335 Picker, supra note 320, at 444.

336 Id.

337 Id. at 445 . 
opening statement. It noted that the Court of Appeals' holding that the plaintiffs were entitled to enjoin the distribution of VCRs, to collect royalties on the sale of such equipment, or to obtain other relief had to be reversed, because otherwise it "would enlarge the scope of [plaintiffs'] statutory monopolies to encompass control over an article of commerce that is not the subject of copyright protection. Such an expansion of the copyright privilege is beyond the limits of the grants authorized by Congress." ${ }^{338}$ If this sounds familiar, it is because the same principles that informed the Court in its rulings on tying and exhaustion were at play again. If the rule of law demands that a person cannot be held liable unless that person was found to breach a distinct legal rule established in the ordinary legal manner, showing that holding a person liable for some harmful activity of another person would provide an efficient way of minimizing the harmful activity is not sufficient to impose such liability. To hold the person liable, a court must be persuaded that a valid law creating such liability exists.

Since copyright law grants the author of a work an exclusive right to reproduce the work, it provides a legal basis for preventing others from reproducing the work, performing it in public, or distributing copies of it. But Sony did not reproduce the plaintiff's works, it did not perform any of them in public, and it did not distribute copies of them; it only sold machines that made it possible for other people to reproduce them. On what basis could the plaintiffs extend their legal control over the reproduction of works to the sale of machines? That was the essential question that the majority confronted.

Justice Stevens rooted his analysis in basic constitutional principles. In the United States, he explained, the Constitution empowers Congress to grant limited monopoly privileges to authors in order to advance public purposes. The task of defining the scope of the limited monopoly that should be granted to authors or to inventors and to decide whether new rules should be fashioned in response to new technologies has been assigned to Congress. ${ }^{339} \mathrm{He}$ noted the "judiciary's reluctance to expand the protections afforded by the copyright without explicit legislative guidance" 340 and concluded that "[i]n a case like this, in which Congress has not plainly marked our course, we must be circumspect in construing the scope of rights created by a legislative enactment which never contemplated such a calculus of interests." ${ }^{341} \mathrm{He}$ explained that sound policy, as well as history, supports such reluctance. ${ }^{342}$

338 Sony, 464 U.S. at 421.

339 Id. at 430.

$340 \mathrm{Id}$. at 431.

$341 \mathrm{Id}$.

342 Id. 
Justice Stevens's analysis relied in part on the text of the Constitution, but his reference to copyright as a legal monopoly flows from and reflects broader principles of the rule of law. As he noted, copyright protection subsists in original works of authorship, but this protection has never extended over all possible uses of the author's work. ${ }^{343}$ Against those who infringe the copyright the Act provides "a potent arsenal of remedies," ${ }^{344}$ but Sony does not reproduce any work; it manufactures and sells VCRs, and there is no statutory provision on the basis of which it could be held liable.

The analysis could have ended here with a dismissal of the plaintiff's claims. But Justice Stevens did not stop there. He noted that the lack of a statutory basis for holding Sony liable does not necessarily mean that there are no applicable general common law principles that could work in tandem with the statute, and that indeed the concepts of vicarious and contributory liability operate throughout the law. ${ }^{345}$ Moreover, because the Court had previously recognized contributory liability in both copyright and patent cases, the Court's task was to determine the bearing of those earlier decisions on the present case. The plaintiffs argued that "that supplying the 'means' to accomplish an infringing activity and encouraging that activity through advertisement are sufficient to establish liability for copyright infringement," and that Kalem Co. v. Harper Brothers stood for that proposition, ${ }^{346}$ but the Court found this argument inapposite. The defendant in Kalem didn't merely provide the "means": it actually produced the infringing film and then arranged for its commercial exhibition. Sony, in contrast, did not supply the infringing copies, but only provided a piece of equipment that could be used for a multitude of purposes, some possibly infringing, others clearly not.

Sony's case, therefore, was more akin to the line of patent cases, some of which were discussed above, in which the Court refused to allow patent owners to extend their monopoly beyond the limit of the patent grant by holding those who distribute unpatented articles to be used in combination with patented devices as contributory infringers. The only cases where the Court allowed contributory liability were those where those articles had no use except through practicing the patented method. ${ }^{347}$ Beyond such cases, finding a supplier of the means that could be used to accomplish infringing and noninfringing acts liable for contributory infringement would effectively mean that the disputed

343 Id. at 432 .

$344 \mathrm{Id}$. at 433.

$345 \mathrm{Id}$. at 436.

346 Id. (citing Kalem Co. v. Harper Brothers, 222 U.S. 55 (1911)).

347 Id. at 441. 
article is within the monopoly granted to the patentee, because it would give the patentee the legal power to control the use of that article. ${ }^{348}$

Justice Stevens rejected the plaintiff's theory not because he calculated that the benefits arising from a narrow rule of contributory liability are greater than the costs of reduced incentive to create new movies, but because accepting it would mean that a copyright owner's monopoly over her work gives her not only a limited control over certain uses of her work, but also control over the sale of VCRs, which are decidedly neither an original work of authorship, nor one which the owner (or her predecessor in title) had authored. ${ }^{349}$

\section{CBS v. Amstrad}

$C B S$ v. Amstrad ${ }^{350}$ is the British equivalent of Sony v. Universal. It involved an action by record labels against Amstrad Consumer Electronics Plc. and Dixons Ltd., the makers and sellers respectively of recording equipment. The record labels argued that it was unlawful for Amstrad to make recording equipment that would be used by members of the public to copy records in which copyright subsists. In the alternative, they argued that Amstrad must not advertise their equipment in such a way as to encourage copying. The plaintiffs alleged infringement of the exclusive right to "authorise" the reproduction of their works, but they also invoked various common law rules hoping to hold Amstrad liable for the unauthorized reproductions of its customers.

The House of Lords, per Lord Templeman, rejected all of the plaintiff's claims. The exclusive right to "authorise" had been previously held to cover "a grant or purported grant, which may be express or implied, of the right

348 Id.

349 It might be tempting to question the validity of this conclusion in light of the Court's judgment in Metro-Goldwyn-Mayer Studios Inc. v. Grokster, Ltd., 545 U.S. 913 (2005). On the one hand, the Court framed the question not as defining the scope of the plaintiff's monopoly, as in Sony, but as optimizing a tradeoff between supporting creative pursuits through copyright protection and promoting innovation in new communication technologies. Id. at 928. Eventually, however, the Court reaffirmed Sony but held that contributory liability could also be based on inducing others to infringe. The Court remanded the case for further determination on the basis that Grokster could be held liable for inducing infringement rather than for distributing the technologies that enable infringement. In this sense Grokster is still consistent with the constitutional principle articulated in Sony because the liability is predicated on particular acts of encouraging others to infringe, rather than on extending the scope of a copyright owner's monopoly from monopoly over the work to monopoly over other articles of commerce.

350 CBS Songs, Ltd. v Amstrad Consumer Elec. Plc. [1988] A.C. 1013 (HL). 
to do the act complained of." But Amstrad did not do any of that. It sold machines that made it possible for the purchaser to copy, but did not grant or purport to grant the right to copy. The decision whether to copy or not remained the user's own. ${ }^{351}$

The Lords equally rejected various claims such as that the defendants became joint infringers with those who purchased the recorders and made copies, because

joint infringers are two or more persons who act in concert with one another pursuant to a common design in the infringement. In the present case there was no common design, Amstrad sold a machine and the purchaser or the operator of the machine decided the purpose for which the machine should from time to time be used. The machine was capable of being used for lawful or unlawful purposes. All recording machines and many other machines are capable of being used for unlawful purposes but manufacturers and retailers are not joint infringers if purchasers choose to break the law. Since Amstrad did not make or authorise other persons to make a record embodying a recording in which copyright subsisted, Amstrad did not entrench upon the exclusive rights granted by the Act of 1956 to copyright owners and Amstrad were not in breach of the duties imposed by the Act. ${ }^{352}$

The plaintiffs further submitted that they were nonetheless entitled to the protection of the common law, and to a remedy against those who disobey the injunction "Thou shalt not steal." That attempt proved futile too. The Lords declined to "enhance the rights of owners of copyright or extend the ambit of infringement." The plaintiff's rights "are derived from statute and not from the Ten Commandments. ... . if [plaintiffs] prove that upon the true construction of the Act Amstrad and Dixons have infringed the rights conferred . . . . by the Act, the court will grant appropriate and effective reliefs and remedies. But the court will not invent additional rights or impose fresh burdens." ${ }^{353}$

So far, these aspects of the House of Lords' judgement are quite similar to Sony. But the rule of law aspects of CBS v. Amstrad are even more pronounced than in Sony. In Sony, Justice Stevens devoted a considerable portion of his reasons to conveying sympathy for Sony and the users of its VCRs. He emphasized the extent of authorized time-shifting, established unauthorized time-shifting as fair use, and concluded that the elected representatives of the millions of Americans who watch television every day could not have

$351 \mathrm{Id}$. at 1053.

$352 \mathrm{Id}$. at 1057.

$353 \mathrm{Id}$. 
intended to make it unlawful to copy a program for later viewing or to prohibit outright the sale of machines that make the copying possible. ${ }^{354}$ In his view, time-shifting of TV programs was a normative and benign activity.

In contrast, Lord Templeman clearly did not seem to share the same attitude towards either Amstrad or the users of its recorders. The House of Lords did not assume that home-taping was permissible. Quite the contrary, the assumption throughout the decision was that the individuals who make the copies are infringers. Lord Templeman did not express much sympathy for Amstrad either. He considered its advertisement "deplorable" because it "flouted the rights of copyright owners," and cynical because it "advertised the increased efficiency of a facility capable of being employed to break the law." But his moral disapproval of Amstrad's business practices was not sufficient for holding liable for authorizing the copying. ${ }^{355}$ Nor did it matter to Lord Templeman that he considered the situation where home copiers must commit millions of breaches of the law every year lamentable from the point of view of society. He opined that a law which is treated with such contempt should be amended or repealed.

If the test for holding providers of copying machines liable were based on a cost-benefit analysis, the plaintiffs in $C B S v$. Amstrad should have won easily: unlike Sony, which, in the eyes of Justice Stevens provided substantial societal benefits, the House of Lords viewed the sale of the tape recorders as resulting in outright loss. But in the end, despite their opposing attitudes to the status quo, adherence to the rule of law compelled the House of Lords to reach the same conclusion as that of the U.S. Supreme Court. Copyright is a creature of statute, and the statute determines its scope. The legislature has granted the copyright owner an exclusive right to reproduce her work, including the exclusive right to authorize others to reproduce it. But this legal monopoly to control certain uses of the work could not be extended by judicial construction to include the power to control the manufacture or sale of machines that facilitate copying. The common law operates in the background and its rules concerning whether and when a person might be liable for the infringing acts of another might apply to infringement of copyright as well, but courts cannot create or extend such rules and thereby extend the scope of the statutory right in such a way that a legal monopoly over an original work of authorship transforms into a monopoly over the sale of "non-works" such

354 Sony Corp. of Am. v. Universal City Studios, Inc., 464 U.S. 417, 456 (1984).

355 Amstrad, [1988] A.C. at 1053. 
as copying machines. If extending the scope of such rights is desirable it's the legislature's job to extend them, not the courts'. ${ }^{356}$

For an economist interested in formulating legal rules that enable efficient enforcement of copyrights, such constitutional limitations on the scope of contributory liability might seem puzzling and frustrating, but from a rule of law perspective they are rather straightforward: a copyright owner's legal monopoly gives it limited powers to prevent others from doing certain acts with respect to its work, and in some limited circumstances the law may also provide a remedy against third parties who contribute or induce the infringement. But without a clear and valid statutory mandate, a copyright owner's monopoly over the work cannot extend to control over non-works, no matter how efficient or inefficient this rule or the contrary might be.

\section{Conclusion}

This Article has explored the rule of law aspects of the intersection between intellectual property, antitrust, and the rule of law. I have argued that the rule of law principle that any restraints on a person's freedom must be grounded in a recognized legal rule has had an important, albeit not always acknowledged, influence on the development of several IP doctrines, including the interface of IP and antitrust law and common law doctrines concerning contracts in restraint of trade and restraints on the alienation of property.

At the heart of the rule of law dimension of IP law lies the recognition that IP rights are monopolies, not in the modern antitrust sense of the word, but in its legal sense, dating back at least to the sixteenth century. IP rights are monopolies because the grant of exclusive rights to inventors and authors allows the owners of such grants to exclude others from doing acts that otherwise they would be free to carry out, and confers upon them regulatory powers over others. Thus, the historical development of IP law has reflected several tensions, both economic and political: the tension between the benefits

$356 I d$. at 1060-61. In a unitary system such as the United Kingdom, the analysis could end here. In a federal system such as the United States or Canada, however, the Constitution adds another layer of complexity. In both countries the federal legislature can enact laws with respect to copyright and patent law for inventions. But granting copyright owners powers to control the manufacture, sale, or use of "non-works," such as copying machines, which are neither works they authored nor new machines they invented, may lie beyond the federal legislative competence over copyrights and patents. If such federal legislative power were to exist, it might have to be found under another federal legislative head of power. 
of free competition and the recognition that some restraints on competition may be beneficial and justified; the concern that power, even when conferred for beneficial purposes that promote the public interest, can often be abused and arbitrarily applied to advance private interests; and the tension between freedom of contract and property and freedom of trade.

I have demonstrated how the rule of law has played an important role in mediating those various tensions, both in its familiar public law aspects but also in its less conspicuous private law dimensions, and how, in particular, it has shaped the development of IP doctrine (and its intersection with antitrust law and the common law) in the United States. My conclusions should not be mistaken for a claim that the rule of law necessarily compels any particular outcome, nor am I suggesting that different outcomes would be unconstitutional. Rather, my analysis wishes to expose the intricate ways in which rule of law considerations, deeply embedded in various doctrines and modes of interpretation, have played out in tilting the courts toward favoring one outcome over another. Sometimes the courts rely on such rule of law moves explicitly, but often they implement them implicitly, perhaps even unconsciously.

The rule of law dimension of IP law offers a different perspective from the contemporary tendency to analyze it using an economically oriented costbenefit analysis. As a member in good standing of the economic approach, I fully appreciate its usefulness, but I am also aware of its limitations. Economic analysis may be helpful in formulating questions, identifying lines of inquiry that are relevant for public policy, as well as providing some answers, but its answers can be indeterminate and contingent on various assumptions and empirical findings, or they might be economically correct, but legally wrong. The law, eventually, is a political institution in the sense that it sets mandatory rules for the polity. Economics may inform the law but cannot replace it. The legal and economic questions surrounding IP, antitrust, and their adjacent common law doctrines are often related, and in many cases both types of considerations might point in the same direction. But there are times when the economic and the legal considerations might point in different directions, or indeterminate directions. In such cases the rule of law might justify or even compel a ruling that might seem puzzling or even misguided to the economic observer. I have shown how the Court's approach to postsale restraints or contributory liability might at times seem as departing from what some economists consider the right answer, but viewed from a rule of law perspective, the approach makes perfect sense.

Lawmakers of course are free to formulate rules that call for a greater or smaller role of decision making based on economic analysis - there is no rule of law principle that would prevent that categorically — but as long as 
the rule of law connotes the supremacy of law, any economic analysis has to comport with the rule of law.

My analysis here has often been positive, in the sense that it describes and explains how rule of law considerations have led the courts to decide in one way rather than another. It is also normative, in the sense that it provides a framework for justifying or criticizing past decisions. I also hope that this Article offers a lens that might prove useful for analyzing and deciding challenging novel questions that will surely present themselves. 
